\title{
Biobased plastics 2019
}

Karin Molenveld en HaRRIËtTe BoS

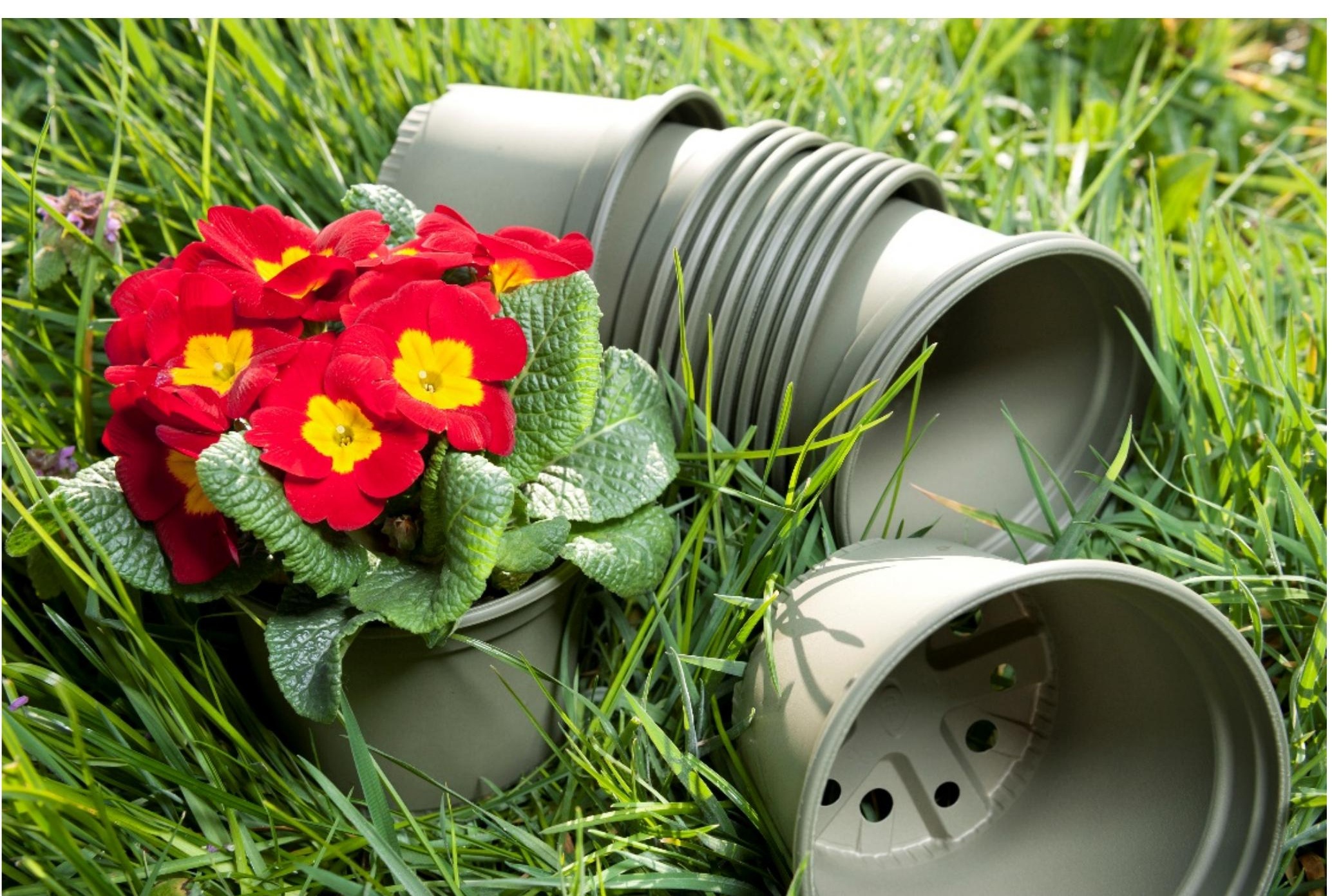





\section{Biobased plastics 2019}

Karin Molenveld en Harriëtte Bos, Wageningen Food \& Biobased Research

Illustratie op de cover: D-grade plantenpotten (Desch Plantpak) 
Uitgegeven in de reeks "Groene Grondstoffen"

- Catalogus biobased bouwmaterialen 2019; Het groene en circulaire bouwen, Jan van Dam, Martien van den Oever (2019)

- Lignine, groene grondstof voor chemicaliën en materialen, Jan van Dam, Paulien Harmsen, Harriëtte Bos, Richard Gosselink (2017)

- Kunstmatige fotosynthese; Voor de omzetting van zonlicht naar brandstof, Robin Purchase, Huib de Vriend en Huub de Groot, editors: Paulien Harmsen en Harriëtte Bos, vertaling: Bruno van Wayenburg (2015)

- Catalogus biobased verpakkingen, Karin Molenveld en Martien van den Oever (2014)

- Groene bouwstenen voor biobased plastics; Biobased routes en marktontwikkeling, Paulien Harmsen, Martijn Hackmann (2012)

- Catalogus biobased bouwmaterialen; Het groene bouwen, Jan van Dam, Martien van den Oever (2012)

- Biocomposieten 2012; Natuurlijke vezels en bioharsen in technische toepassingen, Martien van den Oever, Karin Molenveld, Harriëtte Bos (editor) (2012)

- Biobased Plastics 2012, Christiaan Bolck, Jan Ravenstijn, Karin Molenveld, Paulien Harmsen (editor) (2011)

- Microalgen; het groene goud van de toekomst? Grootschalige duurzame kweek van microalgen voor de productie van bulkgrondstoffen, Hans Wolkers, Maria Barbosa, Dorinde Kleinegris, Rouke Bosma, Rene Wijffels, Paulien Harmsen (editor) (2011)

- Duurzaamheid van biobased producten; Energiegebruik en broeikasgas-emissie van producten met suikers als grondstof, Harriëtte Bos, Sjaak Conijn, Wim Corré, Koen Meesters, Martin Patel (2011)

- Bioraffinage; Naar een optimale verwaarding van biomassa, Bert Annevelink, Paulien Harmsen (2010)

Deze en oudere uitgaven zijn te downloaden van www.groenegrondstoffen.nl 


\section{Voorwoord}

Dit boekje "Bioplastics 2019" uitgegeven in de reeks 'Groene Grondstoffen' is een herziene versie van de uitgave Bioplastics 2012, destijds gemaakt uit een gezamenlijk initiatief van het DPI Value Centre en het Biobased Performance Materials programma. In deze nieuwe uitgave is het overzicht van de stand van zaken van de markt van biobased plastics geactualiseerd. Deze uitgave is op verzoek van het Ministerie van Economische Zaken en Klimaat en de TKI-BBE tot stand gekomen.

Dit boekje geeft inzicht in de huidige op de markt verkrijgbare biobased plastics en de te verwachten ontwikkelingen. Er wordt gekeken naar zowel thermoplastische als thermohardende materialen. Het boekje biedt inzicht in de productie, verwerking, eigenschappen en toepassingsmogelijkheden van de verschillende typen bioplastics. Daarnaast worden mogelijke toepassingen, afvalbeheer en technische-, economischeen milieu-uitdagingen verder toegelicht.

Biobased plastics 2019 is geschreven voor iedereen die meer wil weten over biobased plastics, hetzij vanuit maatschappelijk of bedrijfsmatig belang, of gewoon vanuit interesse in de huidige stand van zaken. Doel is ondernemers de mogelijkheden van biobased plastics te laten zien, studenten informatie te geven over deze nieuwe onderzoeksrichting en ambtenaren te ondersteunen in hun beleidsvorming. 



\section{I nhoudsopgave}

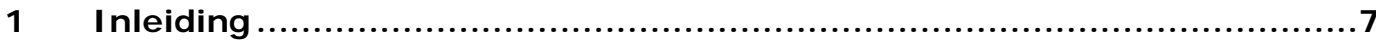

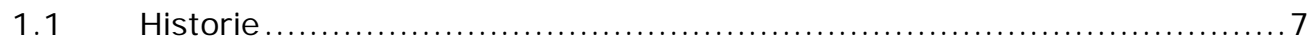

1.2 Bioplastics binnen "de nieuwe circulaire economie" ......................... 8

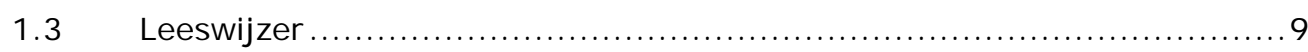

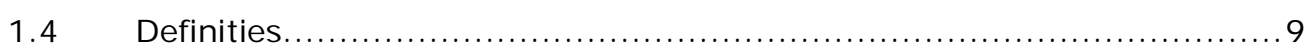

2 Thermoplasten op basis van biobased monomeren...............................13

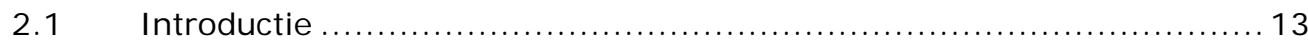

$2.2 \quad$ Biobased polyesters............................................................. 13

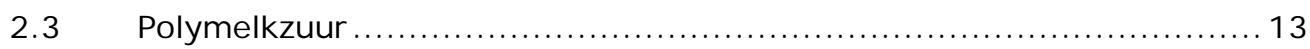

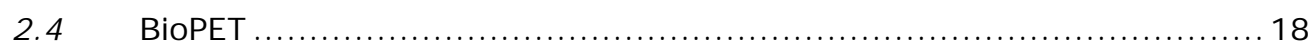

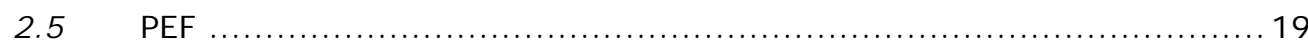

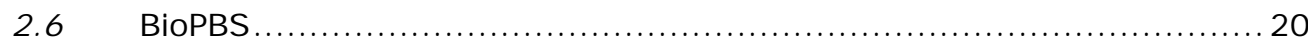

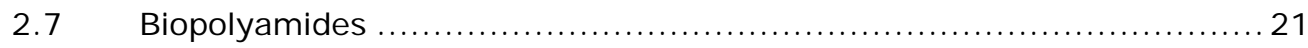

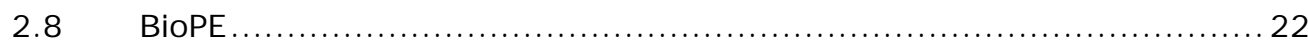

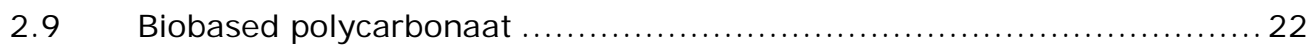

2.10 Biobased thermoplastische elastomeren ................................... 22

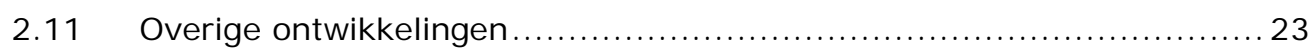

3 Thermoharders op basis van biobased monomeren ............................25

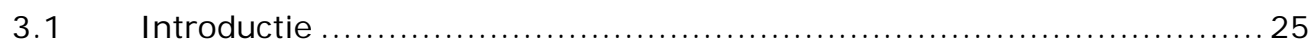

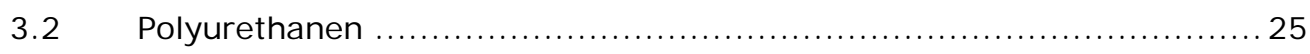

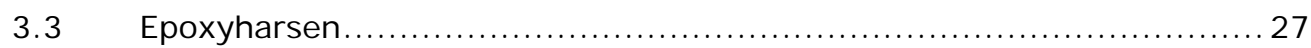

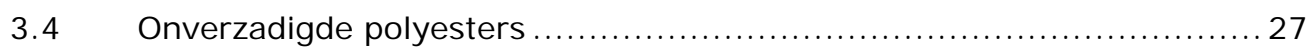

3.5 Alternatieve vetzuur gebaseerde reactieve systemen .................... 28

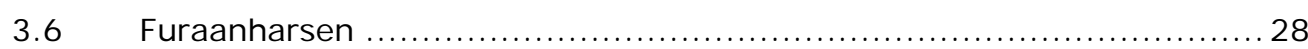

4 Biobased plastics op basis van natuurlijke polymeren .........................29

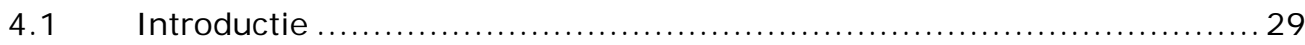

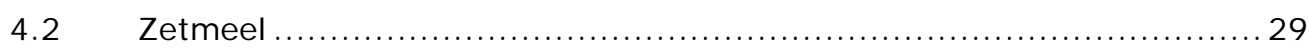

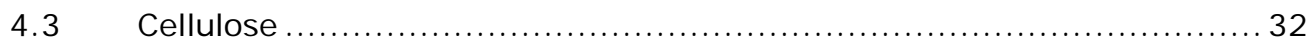

4.4 Biobased polymeren uit micro-organismen ................................. 36

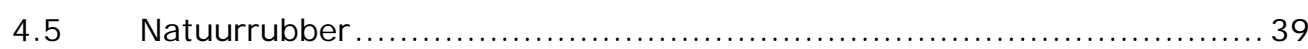

$5 \quad$ Verwerking van biobased plastics tot producten ...............................41

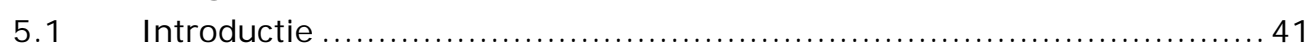

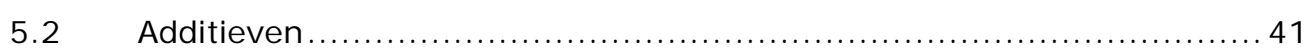

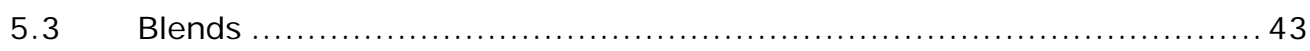

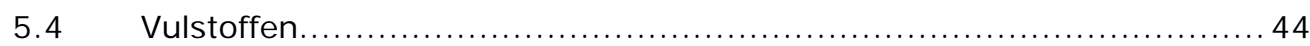

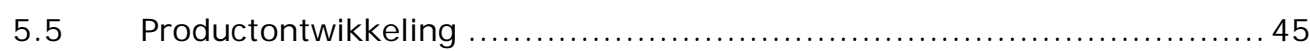




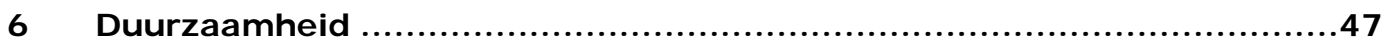

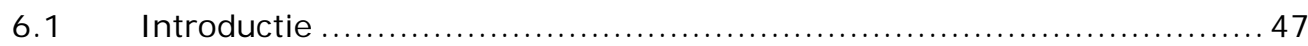

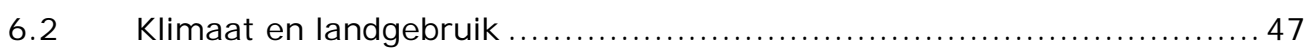

6.3 Beschikbaarheid van biomassa..................................... 48

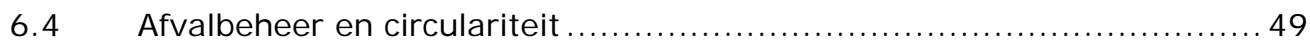

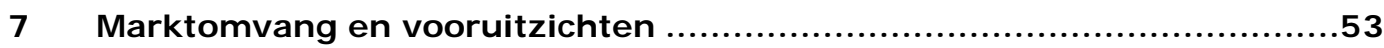

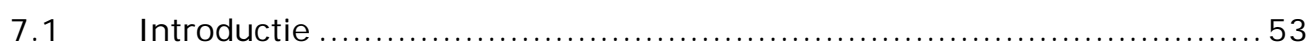

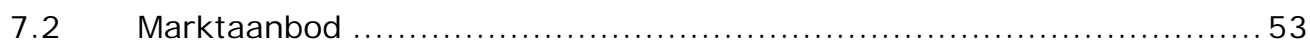

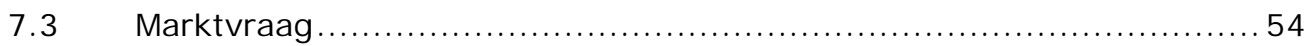

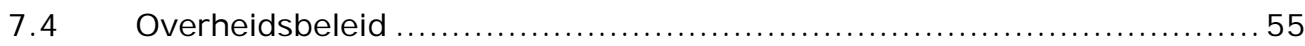

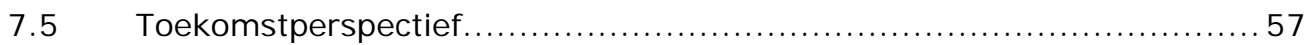

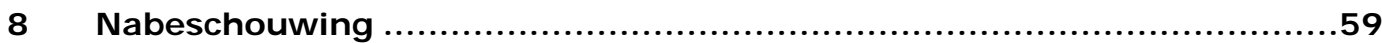

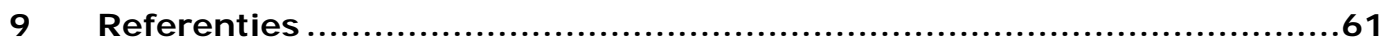

10 Verklarende woordenlijst ........................................................63 


\section{I nleiding}

\subsection{Historie}

Sinds mensenheugenis worden natuurlijke polymeren zoals hout en katoen gebruikt voor voedsel, kleding en constructiemateriaal. De industriële revolutie leidde tot de opkomst van de eerste (door de mens gemaakte) biobased plastics of kunststoffen. Celluloid, een materiaal op basis van cellulose, werd ontdekt rond 1860 en werd voor de eeuwwisseling al toegepast als vervanger van ivoor. Kort daarna werden rayon en cellofaan geïntroduceerd als textielvezel en verpakkingsfolie.

In de eerste helft van de twintigste eeuw kreeg een ander soort polymeren echter de overhand. Ze werden geproduceerd uit petrochemische grondstoffen, voornamelijk aardolie. Materialen op basis van deze polymeren hebben een enorme groei laten zien in de afgelopen eeuw en worden synthetische plastics genoemd.

De tijden zijn veranderd en momenteel staan biobased plastics in de schijnwerpers vanwege zorgen om het klimaat en afnemende oliereserves, maar ook als gevolg van technologische ontwikkelingen in bijvoorbeeld de industriële biotechnologie en toenemende zorgen over milieuvervuiling door plastic afval. Het gebruik van biobased polymeren wordt opnieuw ontdekt, zoals de toepassing van zetmeel als thermoplastisch materiaal en polymelkzuur als een veelbelovend nieuw plastic voor bulk-toepassingen. Ook worden innovatieve biotechnologische productietechnologieën ontwikkeld om polymeren en bouwstenen voor polymeren te produceren door micro-organismen.

Biobased plastics worden gedefinieerd als door de mens gemaakte of door de mens verwerkte biologische macromoleculen, afgeleid van biologische hulpbronnen voor thermoplastische en thermohardende toepassingen, zowel voor bulk als voor technische toepassingen. Deze klasse van materialen is een subgroep van de biobased polymere materialen waaronder materialen vallen zoals hout, papier en karton, bepaalde soorten verf en katoen.

Sinds het begin van deze eeuw is er opmerkelijke vooruitgang geboekt op het gebied van de productie van biobased plastics. Nieuwe typen polymeren en nieuwe technologieën leiden tot veel bredere toepassingsmogelijkheden. Ook van oorsprong petrochemische bedrijven en multinationals doen inmiddels mee aan de ontwikkeling, waardoor nieuwe biobased plastics in een toenemend tempo op de markt worden geïntroduceerd.

De belangrijkste grondstoffen die momenteel worden gebruikt om biobased plastics te maken zijn koolhydraten en met name zetmeel, maar ook suikers en cellulose. 
Daarnaast worden natuurlijke oliën zoals palm-, soja- en castor- en lijnzaadolie toegepast. Ook andere bestanddelen uit de plant zoals eiwitten en lignine kunnen worden ingezet, en ook grondstoffen van dierlijke oorsprong zoals chitine van schaaldieren. De mogelijkheden van biomassa uit zee worden momenteel met grote interesse bekeken; zo worden micro- en macroalgen (wieren) gezien als een nieuwe potentiële bron voor koolhydraten, natuurlijke oliën en proteïnen.

\subsection{Bioplastics binnen "de nieuwe circulaire economie"}

Plastic worden in het algemeen geassocieerd met veel milieuproblemen die variëren van een toename van het broeikasgaseffect tot zwerfafval, microplastics en "de plastic soep". De Ellen McArthur Foundation heeft in een model geschetst hoe "de nieuwe plastic economie" eruit moet zien. Dit model wordt breed geaccepteerd en er wordt beleid op geformuleerd vanuit overheden maar ook vanuit het bedrijfsleven. De drie belangrijkste elementen van "de nieuwe plastic economie "zijn:

1. Alle plastics moeten zoveel mogelijk circulair worden gebruikt (gerecycled) in gelijkwaardige toepassingen

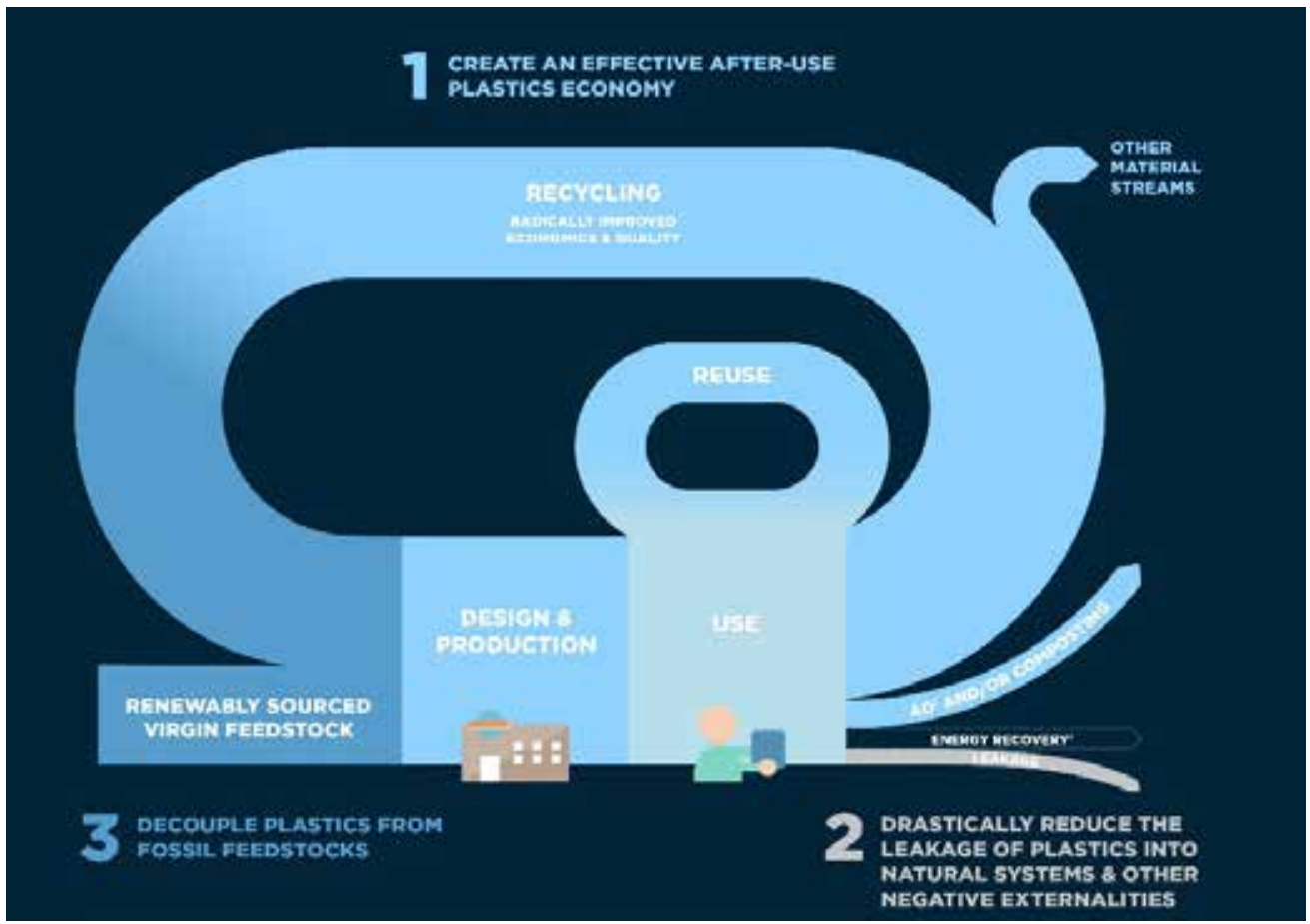

De “nieuwe plastic economie"(Ellen Mac Arthur Foundation)

${ }^{1}$ www. ellenmacarthurfoundation.org/our-work/activities/new-plastics-economy 
2. Lekkage van kunststoffen in het milieu moet worden voorkomen

3. De productie van virgin plastics wordt losgekoppeld van fossiele grondstoffen.

Biobased plastics zijn een belangrijk element van dit nieuwe model vanwege de loskoppeling van fossiele grondstoffen. Recyclebaarheid van biobased plastics is daarbij een voorwaarde. Daarnaast kunnen biologisch afbreekbare kunststoffen worden ingezet in producten waarin niet voorkomen kan worden dat deze in het milieu terecht komen.

\subsection{Leeswijzer}

In de volgende drie hoofdstukken worden de belangrijkste commercieel beschikbare biobased plastics besproken. Hoofdstukken 2 en 3 zijn gewijd aan biobased plastics gebaseerd op biobased monomeren, zowel de thermoplasten als de thermoharders. Hoofdstuk 4 zal ingaan op kunststoffen op basis van door de natuur of micro-organismen gemaakte polymeren. In elk hoofdstuk zal waar relevant worden ingegaan op technische aspecten zoals productie, verwerking, toepassingsmogelijkheden en technologische ontwikkelingen, maar ook andere aspecten zoals prijs en de beschikbaarheid worden behandeld. Vervolgens wordt in hoofdstuk 5 uitgelegd op welke wijze van deze biobased plastics, met behulp van additieven, vulstoffen en blenden, producten gemaakt kunnen worden.

In hoofdstuk 6 komen vervolgens de belangrijkste duurzaamheid-gerelateerde aspecten aan bod rondom thema's zoals beschikbaarheid en productie van biomassa, effect op het klimaat, bioraffinage, afvalbeheer, circulariteit en GMO. Hoofdstuk 7 zal marktvraag en -aanbod belichten, ingaan op de effecten van overheidsbeleid en een perspectief schetsen richting de toekomst. In de nabeschouwing in hoofdstuk 8 worden de meest recente ontwikkelingen besproken die een belangrijke rol zullen gaan spelen in de verdere ontwikkeling van biobased plastics. Achterin staan een index en een verklarende woordenlijst met uitleg van de technische termen en gebruikte afkortingen.

\subsection{Definities}

Om de leesbaarheid te vergroten volgt hieronder een uitleg van veelvuldig gebruikte begrippen en vaktermen:

Bioplastics

Een term die zowel wordt gebruikt voor biologisch afbreekbare plastics als voor hernieuwbare plastics en daarom verwarring kan veroorzaken. In het verleden werd met deze term voornamelijk biologisch afbreekbaar plastic bedoeld. Momenteel ligt de focus bij bioplastics vooral op het hernieuwbare karakter (biobased); deze plastics zijn dus niet per definitie biologisch afbreekbaar. Om verwarring te voorkomen is het beter om de termen biobased plastics en biologisch afbreekbare plastics te gebruiken. 
Biobased content

Het deel of percentage van het gewicht van een product dat is gebaseerd op hernieuwbare grondstoffen. In eerste instantie werd in de bepaling van de biobased content alleen de hoeveelheid recent opgeslagen koolstof in een product meegenomen. Voor deze zogenaamde C14-methode zijn diverse normen beschikbaar (ASTM D6866, ISO 16620-4 en 16640)) waarmee dus de "biobased carbon content" bepaald kan worden. Sinds 2016 is er een (Europese) EN norm beschikbaar (EN 16785-1) waarbij naast koolstof ook andere elementen zoals zuurstof en stikstof worden meegenomen in de biobased content bepaling.

Gecertificeerd hernieuwbaar of biobased

Enkele grote petrochemische producenten brengen plastics op de markt die gecertificeerd biobased genoemd worden. Deze producenten voegen een percentage biomassa toe als grondstof voor hun naftakrakers. Op basis van de toegevoegde hoeveelheid biomassa wordt via een massabalans methode aan een evenredig deel van de geproduceerde plastics het certificaat "hernieuwbaar" toegekend. Omdat van deze plastics het biobased gehalte niet meetbaar is via eerdergenoemde meetmethoden mogen ze niet "biobased" genoemd worden maar "gecertificeerd biobased" of "gecertificeerd hernieuwbaar".

Biologisch afbreekbaar of biodegradeerbaar

Plastics die door micro-organismen (bacteriën of schimmels) afgebroken kunnen worden tot water en kooldioxide $\left(\mathrm{CO}_{2}\right)$ en/of methaan. Of een materiaal biologisch afbreekbaar is hangt mede af van de chemische structuur. Zo kunnen bijvoorbeeld bepaalde polyesters afgebroken worden door micro-organismen door de aanwezigheid van esterverbindingen. Polymeren zoals polyethyleen (PE) en polypropyleen (PP) bevatten alleen koolstof en waterstof en kunnen daarom zeer moeilijk door bacteriën of schimmels worden afgebroken. Naast de chemische structuur zijn omgevingsfactoren belangrijk voor de mate en snelheid van biologische afbraak. Voorbeelden van omgevingsfactoren zijn temperatuur, beschikbaarheid van zuurstof, beschikbaarheid van water, het type en de hoeveelheid micro-organismen (schimmels en bacteriën).

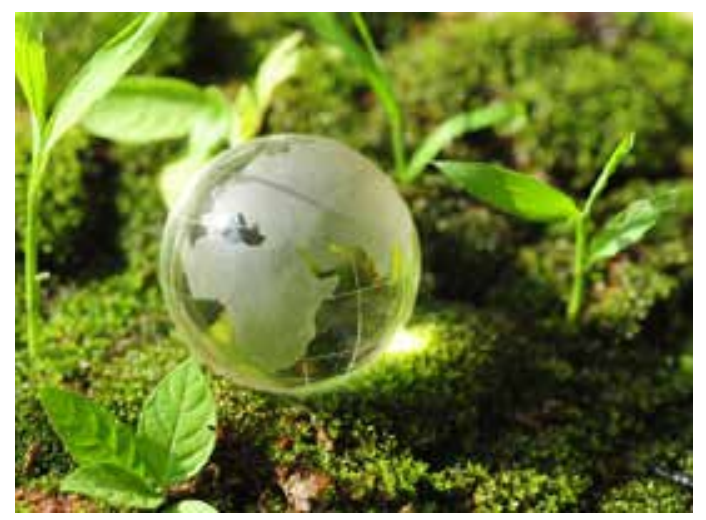


Composteerbare plastics

Plastic verpakkingen die voldoen aan EN13432, een internationale norm voor composteerbare plastics, en die in industriële composteringsinstallaties (onder gecontroleerde omstandigheden) voldoende snel afbreken. De EN norm definieert hoe snel en in welke mate een biologisch afbreekbaar plastic moet degraderen onder commerciële composteringscondities.

Of een plastic product composteerbaar is hangt mede af van de productgeometrie en eventuele additieven. Zo is het mogelijk dat een product van een biodegradeerbaar polymeer zoals PLA niet composteerbaar is doordat het product te dik is (voor PLA laagdikte $>2 \mathrm{~mm}$ ) of omdat het zware metalen uit bijvoorbeeld kleurstoffen bevat. In de afgelopen jaren zijn industriële composteerprocessen sterk veranderd waarbij het doel is het composteringsproces zo snel mogelijk te laten verlopen. $\mathrm{Er}$ is daardoor onduidelijkheid ontstaan of producten die voldoen aan EN13432 voldoende snel afbreken in de huidige composteerinstallaties. Hiervoor is aanvullend onderzoek nodig onder praktijkcondities.

\section{EN13432}

Volgens deze norm kan een plastic verpakking alleen composteerbaar genoemd worden indien wordt aangetoond dat

- Het materiaal en zijn relevante organische bestanddelen van nature biologisch afbreekbaar zijn

- Desintegratie van het materiaal plaatsvindt in een composteringsproces voor biologisch afval

- Het product geen negatieve invloed heeft op het composteringsproces

- De kwaliteit van de compost niet negatief wordt beïnvloed door het product

\section{Oxodegradeerbaar}

Oxodegradeerbare plastics zijn materialen waaraan additieven zijn toegevoegd zodat ze onder invloed van zuurstof (uit de lucht) uiteenvallen. Tot op heden zijn er nog geen oxodegradeerbare producten op de markt die voldoen aan de eisen van de EN13432 norm. Er zijn zorgen dat oxodegradeerbare plastics bijdragen aan milieuvervuiling via de vorming van microplastics. De EU heeft begin 2018 een rapport uitgebracht dat oproept om maatregelen te nemen tegen het gebruik van basede-degradeerbare plastics ${ }^{2}$.

2 http://ec.europa.eu/environment/circular-economy/pdf/oxo- plastics. pdf 
Indeling

Mede op basis van bovengenoemde definities kunnen plastics worden ingedeeld volgens onderstaand overzicht waarin enkele voorbeelden zijn weergegeven:

\begin{tabular}{|c|c|c|c|}
\hline & Petrochemisch & Gedeeltelijk biobased & Biobased \\
\hline Niet biologisch afbreekbaar & PE & Bio-PET & Nylon 11 \\
\hline Biologisch afbreekbaar & PCL & Zetmeelblends & PLA \\
\hline
\end{tabular}

Petrochemisch:

Op basis van aardolie

Gedeeltelijk biobased:

Plastics op basis van zowel aardolie als hernieuwbare grondstoffen

Biobased:

Volledig uit hernieuwbare grondstoffen

Let op dat plastics gedeeltelijk biobased kunnen zijn maar niet gedeeltelijk biologisch afbreekbaar omdat dit kan leiden tot de vorming van microplastics. 


\section{Thermoplasten op basis van biobased monomeren}

\subsection{Introductie}

Thermoplasten zijn materialen waarvan de polymere ketens niet onderling zijn verknoopt en die bij verhitting zacht worden of smelten. Ten aanzien van biobased thermoplasten kunnen twee ontwikkelingen worden onderscheiden:

Productie van biobased polymeren die chemisch identiek zijn aan bestaande petrochemische polymeren

Voorbeelden zijn biopolyethyleen (bioPE), diverse polyamides en polyesters. Omdat deze biobased polymeren identiek zijn aan hun petrochemische tegenhangers hebben deze materialen identieke eigenschappen. Toepassing van bioPE levert producten die gelijk zijn aan producten die worden gemaakt uit PE van petrochemische oorsprong.

Productie van volledig nieuwe monomeren en polymeren op basis van biobased grondstoffen

Voorbeelden van polymeren die niet gemaakt (kunnen) worden op basis van petrochemische bouwstenen zijn polymelkzuur, furaan-gebaseerde polyesters, polyesters op basis van 1,3-propaandiol en enkele polyamides zoals nylon 11. Deze polymeren hebben unieke eigenschappen en vragen meer onderzoek op het gebied van verwerking, gebruik van additieven en productontwikkeling.

\subsection{Biobased polyesters}

\subsubsection{Introductie}

Polyesters zijn polymeren waarvan de monomeren worden verbonden via een ester binding. Ze kunnen worden geproduceerd door polycondensatie van een di-zuur en een di-alcohol, door polycondensatie van een hydroxy-zuur of via ring-opening polymerisatie van een lacton. Deze biobased bouwstenen kunnen geproduceerd worden door microorganismen (fermentatieve processen) of via chemische routes. Omdat biobased grondstoffen van nature veel meer zuurstof bevatten dan petrochemische grondstoffen is de productie van (de bouwstenen) voor biobased polyesters vaak efficiënter dan de productie van polyolefinen en zijn de productieroutes eerder prijscompetitief.

\subsection{Polymelkzuur}

Polymelkzuur (PLA) is op dit moment de belangrijkste biobased polyester en één van de meest aansprekende voorbeelden van een $100 \%$ biobased polymeer. PLA heeft goede eigenschappen: het is stijf, transparant en glossy en composteerbaar in industriële composteerinstallaties. 
PLA is van oorsprong een duur polymeer ( $>€ 50 / \mathrm{kg}$ ) dat voornamelijk werd gebruikt in de biomedische industrie (implantaten en hechtdraad). Door de ontwikkeling van efficiënte bulkpolymerisatieprocessen is het op dit moment één van de goedkoopste biobased plastics met een prijs van $€ 2-3 / \mathrm{kg}$ afhankelijk van de specifieke kwaliteit (grade) en producent. Deze relatief lage prijs, die de afgelopen jaren ook stabiel is geweest, heeft voor veel bedrijven de overstap naar biobased polymeren aantrekkelijker gemaakt. De beschikbaarheid van PLA is goed, met een grote productielocatie van 150 kton per jaar in Amerika, een grote productielocatie ( $75 \mathrm{kton}$ ) in Thailand en diverse kleinere productielocaties in China en Europa.

\subsubsection{Productie van PLA}

PLA werd tot voor kort hoofdzakelijk geproduceerd in Amerika uit maïszetmeel. Omdat in Noord Amerika genetisch gemodificeerde maïs wordt verbouwd, wordt deze maïs ook gebruikt als grondstof voor PLA. In enkele Europese landen is het gebruik van dergelijke gewassen echter omstreden. Op de Europese markt is daaom ook PLA verkrijgbaar die uit niet-gemodificeerde mais is geproduceerd.

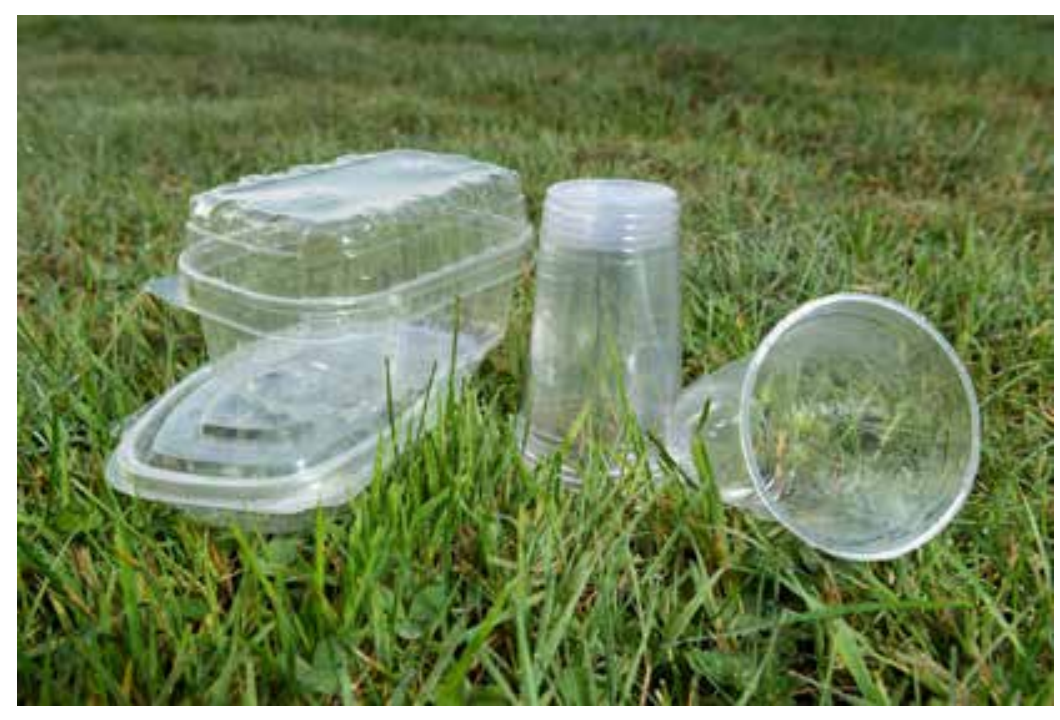

Gethermovormde producten van PLA (NatureWorks)

Om PLA te maken is geen genetisch gemodificeerde maïs nodig; PLA kan in principe van elke grondstof die zetmeel (aardappel, tapioca) of suiker (suikerbieten, suikerriet) bevat worden gemaakt. Doorgaans is de gebruikte grondstof afhankelijk van de lokale beschikbaarheid, en zo is in Thailand suikerriet de voornaamste grondstof voor PLA. 
Uit zetmeel of suikers wordt via fermentatie melkzuur geproduceerd. Deze omzetting is zeer efficiënt. Per suikermolecuul worden twee melkzuurmoleculen gevormd zonder dat er bijproducten ontstaan. PLA kan niet direct worden geproduceerd uit melkzuur via een bulk polycondensatieproces. Dit proces resulteert in een polymeer met een te lage molecuulmassa en slechte eigenschappen. PLA met goede eigenschappen wordt geproduceerd uit lactides (cyclische dimeren van melkzuur) via een zeer efficiënte ringopening polymerisatie.

Melkzuur is een chirale (optisch actieve) verbinding en komt voor in twee vormen ( $L$ - en D-melkzuur). Via polymerisatie kunnen er verschillende polymeren worden gevormd, zuiver L- of D-polymelkzuur, of een copolymeer van $L$ - en D-melkzuur. De eigenschappen van PLA zijn afhankelijk van de stereo-chemische zuiverheid ( $L$ en $D$ gehalte). Puur poly L-melkzuur (PLLA) of poly D-melkzuur (PDLA) heeft een kristalliniteit van ongeveer $37 \%$, een glasovergangstemperatuur $\left(T_{g}\right)$ van $60{ }^{\circ} \mathrm{C}$ en een smelttemperatuur van $175^{\circ} \mathrm{C}$. De meeste commercieel beschikbare PLA grades bestaan uit 85 tot $99 \%$ L-melkzuur en 15 tot $1 \%$ D-melkzuur. Met een toenemende hoeveelheid D-isomeer wordt het materiaal minder kristallijn, kristalliseert het minder snel en wordt het smeltpunt lager. PLA met een D-gehalte van $10 \%$ of meer is volledig amorf.

\subsubsection{Verwerking van PLA}

PLA kan worden verwerkt via de voor thermoplastische materialen gebruikelijke verwerkingstechnieken, waaronder het spinnen van vezels, extrusie en compounderen, spuitgieten en thermovormen. Verwerkingstemperaturen variëren tussen $180{ }^{\circ} \mathrm{C}$ en $220^{\circ} \mathrm{C}$ afhankelijk van het type PLA en de verwerkingstechniek.

Zoals alle polyester moet PLA voordat het in de smelt wordt verwerkt gedroogd worden (watergehalte $<250 \mathrm{ppm}$ ). PLA heeft een relatief lage smeltsterkte en folieblazen of extrusieschuimen is niet mogelijk zonder toevoeging van additieven die de smeltsterkte verbeteren of het PLA te blenden met andere polymeren. Productie van expandable bead schuim (piepschuim) en biaxiaal verstrekte folies is wel goed mogelijk. Ook wordt PLA veel gebruikt in 3D-print toepassingen.

De kristallisatiesnelheid van de meeste commercieel beschikbare PLA's is laag. Daardoor is een product van PLA vaak volledig amorf. De maximale gebruikstemperatuur (heat deflection temperature, HDT) van een amorf PLA product is ongeveer $55^{\circ} \mathrm{C}$. Commercieel beschikbare transparante (gethermovormde) PLA bekers zijn daarom alleen geschikt voor koude dranken. In een warm klimaat levert deze lage maximale gebruikstemperatuur problemen op, maar ook in een kouder klimaat kunnen problemen ontstaan met dergelijke PLA-producten wanneer deze worden bewaard op een warme plaats zoals achter glas in het zonlicht of in een gesloten container.

Wanneer gebruik wordt gemaakt van specifieke PLA grades in combinatie met de juiste procesomstandigheden is het goed mogelijk producten met een hoge kristalliniteit te 
maken. Een goed voorbeeld zijn PLA-koffiebekers die standaard polystyreen (PS) bekers kunnen vervangen.

\subsubsection{Eigenschappen van PLA}

Voordelen van PLA in vergelijking met andere biopolymeren zijn de relatief lage prijs, de commerciële beschikbaarheid van verschillende grades (voor veel processen en toepassingen), de transparantie, de hoge glans en de hoge stijfheid. PLA kan in veel toepassingen polystyreen of PET vervangen. Nadelen van PLA zijn de eerder genoemde lage HDT en smeltsterkte, en de gevoeligheid voor hydrolyse (wanneer het niet goed is gedroogd) tijdens de verwerking. Een ander nadeel van PLA is dat het materiaal van zichzelf bros is en een lage scheursterkte heeft.

De afgelopen jaren zijn veel additieven en masterbatches ontwikkeld die toegevoegd kunnen worden om de eigenschappen van PLA te verbeteren. Voorbeelden zijn additieven die de slagvastheid kunnen verbeteren (impact modifiers) en ketenverlengers (chain-extenders) die de smeltsterkte verhogen. Een aantal van deze additieven kan een negatieve invloed hebben op de transparantie en/ of composteerbaarheid. Daarnaast kunnen eigenschappen worden verbeterd door te blenden met andere (biobased) polymeren. De meest bekende PLA blend is die met PBAT (polybutyleen adipaat tereftalaat). Deze petrochemische biologisch afbreekbare polyester maakt PLA taai en breder toepasbaar. Meer informatie over het verbeteren van de materiaaleigenschappen van biobased plastics is terug te vinden in hoofdstuk 5 .

PLA is composteerbaar in industriële composteringsinstallaties en is niet geschikt voor thuiscomposteren. Het is belangrijk dat tijdens het composteringsproces de temperatuur hoog genoeg is (circa $60{ }^{\circ} \mathrm{C}$ ). Onder thermofiele anaerobe condities kan PLA vergist worden (voor methaan productie). Een alternatief end-of-life scenario is hydrolyse van PLA tot het monomeer melkzuur, gevolgd door opnieuw de productie van lactides en PLA. Dit noemen we chemische recycling. Daarnaast kan PLA mechanisch gerecycled worden.

\subsubsection{Toepassingen van PLA}

PLA als biobased en composteerbare kunststof werd in eerste instantie vooral toegepast in verpakkingsmaterialen, disposables en vezels (textiel en non-wovens). Voorbeelden van op de markt beschikbare verpakkingsmaterialen en disposables op basis van PLA zijn onder andere transparante folies, wegwerp-bestek, gethermovormde producten zoals bekers, bloempotjes en vleesschaaltjes en geschuimde transportverpakkingen. Vezeltoepassingen van PLA zijn bijvoorbeeld theezakjes, luiers en tissues maar ook bedtextiel, tapijt en gordijnen. Ook wordt PLA toegepast als papiercoating (koffiebekers) en in lijmen waaronder hotmelts. Er is een toenemende vraag naar PLA voor het gebruik in duurzame toepassingen zoals elektronica, automobielonderdelen en producten voor 
de bouw. Hittebestendig PLA (PLA met een hoge HDT) helpt om deze nieuwe toepassingen mogelijk te maken. Hiervoor kan PLA eventueel gevuld worden met glasvezels. Voorbeelden van bouwtoepassingen zijn PLA schuim (isolatiemateriaal), wandbekleding, vloerbedekking en profielen voor de bescherming van wanden en deuren.

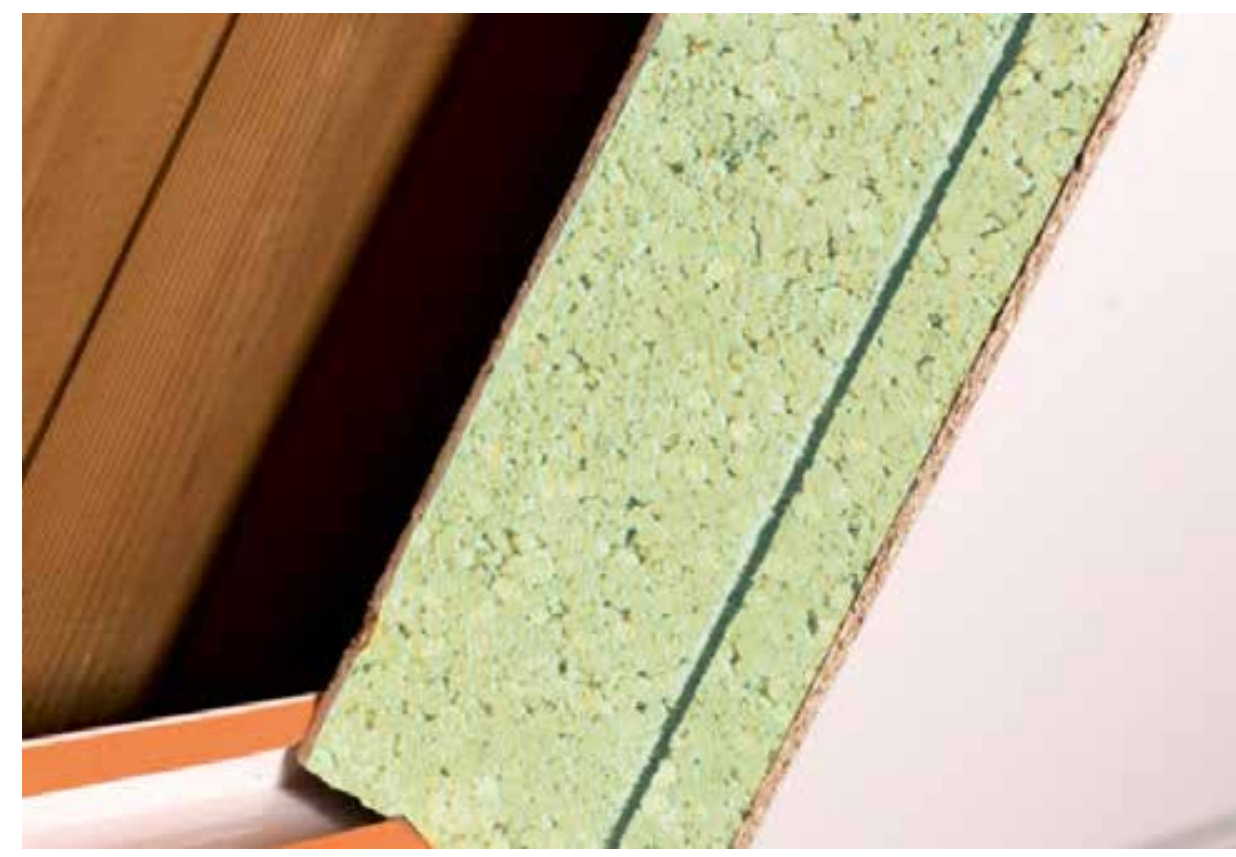

Biofoam isolatiemateriaal (piepschuim op basis van PLA, Bewi-Synbra)

\subsubsection{Ontwikkelingen op het gebied van PLA}

De belangrijkste ontwikkeling op het gebied van PLA is het maken van producten met een hoge temperatuurbestendigheid. Dit is mogelijk via blenden met biobased of petrochemische kunststoffen of door PLA sneller te laten kristalliseren. Aangetoond is dat met behulp van nucleating agents (kiemvormers) zoals talk, EBS (ethyleen-bisstearamide) maar ook PDLA (poly D-melkzuur) de kristallisatiesnelheid van PLA sterk toeneemt. Het meest effectief en veelbelovend in dit opzicht is het gebruik van PDLA voor de vorming van sc-PLA (stereocomplex PLA). Sc-PLA wordt gevormd door cokristallisatie van PLLA en PDLA en heeft een smeltpunt van $230^{\circ} \mathrm{C}$. Doorgaans is het gebruik van nucleating agents niet voldoende om te komen tot een hittebestendig product, maar moeten ook de procesomstandigheden worden aangepast. Voorbeelden zijn spuitgieten en thermovormen met een verwarmde matrijs (ca. $100^{\circ} \mathrm{C}$ ). 
Een andere ontwikkeling is het gebruik van blends met andere biobased polymeren voor de optimalisatie van eigenschappen zoals taaiheid en scheursterkte. Ook op het gebied van grondstofgebruik zijn er ontwikkelingen. Hierbij moet gedacht worden aan de inzet van specifieke reststromen voor de productie van melkzuur, maar ook aan de productie van melkzuur uit methaan.

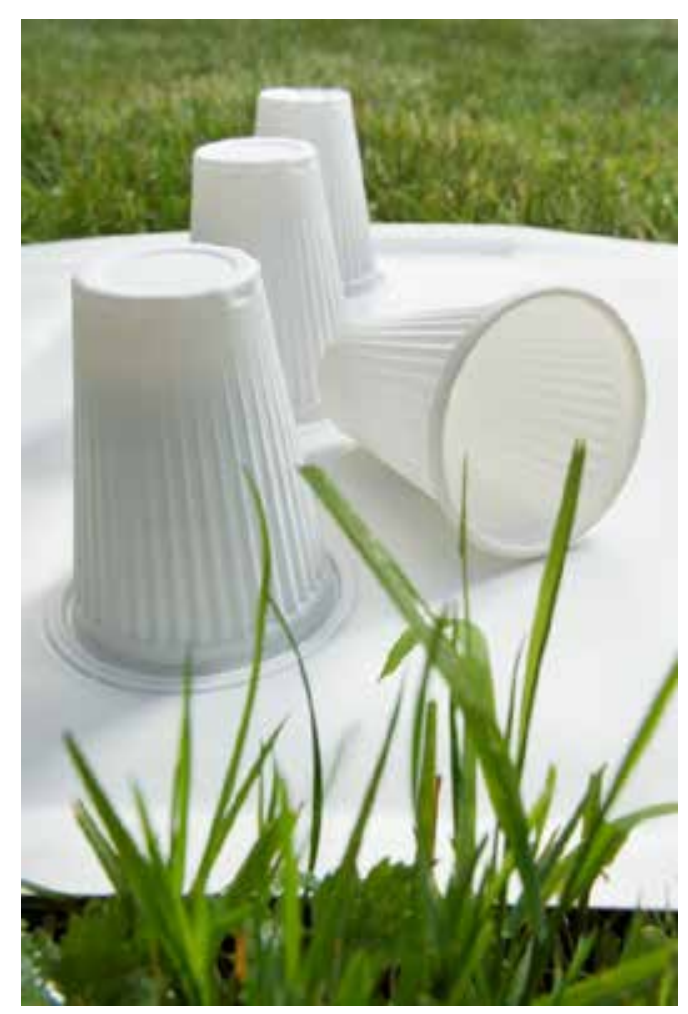

Koffiebekers op basis van PLA (Corbion)

\subsection{BioPET}

PET (polyethyleentereftalaat) behoort tot de 5 meest verkochte plastics wereldwijd. Tweederde van het wereldwijde productievolume wordt gebruikt voor de productie van vezels (zoals bijvoorbeeld voor fleece truien) en eenderde voor verpakkingen waarbij de PET-fles voor frisdrank het meest bekend is. In 2009 heeft Coca-Cola de 'plant bottle' gelanceerd die wordt gemaakt uit bioPET. BioPET is een voorbeeld van een gedeeltelijk biobased polyester en heeft exact dezelfde chemische structuur en eigenschappen als traditioneel PET. BioPET kan dus eenvoudig worden geïmplementeerd in producten en 
zonder problemen worden mee verwerkt met bestaande recycle stromen. Op basis van het productievolume is BioPET op dit moment de belangrijkste biobased plastic.

PET wordt geproduceerd door polymerisatie van ethyleenglycol en tereftaalzuur. Voor de huidige commercieel beschikbare bioPET wordt ethyleenglycol uit biologische grondstoffen gepolymeriseerd met op aardolie gebaseerd tereftaalzuur. Op basis van het aantal koolstofatomen is bioPET $20 \%$ biobased. Toch geeft deze bioPET een milieuwinst wat betreft $\mathrm{CO}_{2}$ uitstoot en de uitputting van energie bronnen.

Een volgende stap is de ontwikkeling van $100 \%$ bio-PET en hiervoor moet dus ook de tweede bouwsteen, tereftaalzuur, gemaakt worden uit biobased grondstoffen. Technisch is de productie van biobased tereftaalzuur mogelijk, maar wel complex. Routes die ontwikkeld worden zijn zeer divers en variëren van chemische routes, tot een combinatie van fermentatie en chemische processtappen. Kenmerkend is dat er meerdere processtappen noodzakelijk zijn. Mogelijke biobased grondstoffen (uitgangsmaterialen) voor de synthese van biobased tereftaalzuur zijn suikers of lignine. Vanwege de complexiteit van de productie van biobased tereftaalzuur richt onderzoek zich op de ontwikkeling van meer economische productieroutes maar inmiddels ook op de opschaling van ontwikkelde productieroutes.

\subsubsection{Aan bioPET gerelateerde ontwikkelingen}

In plaats van bio-ethyleenglycol wordt ook 1,3-propaandiol (PDO) gepolymeriseerd in combinatie met tereftaalzuur voor de productie van polytrimethyleen tereftalaat (PTT). PDO wordt via fermentatie geproduceerd uit zetmeel. In 2000 is PTT, dat veel lijkt op PET gecommercialiseerd. PTT wordt momenteel vooral toegepast in tapijt- en textielvezels. Voordelen zijn een iets hoger biobased gehalte, maar met name specifieke eigenschappen zoals de veerkracht en hogere rek van het materiaal.

Een andere interessante variatie op PET is polyethyleenisosorbide tereftalaat (PEIT). In PEIT wordt een deel van de ethyleenglycol vervangen door isosorbide. Isosorbide wordt via dehydratatie geproduceerd uit sorbitol, een zoetstof die wordt gemaakt door hydrogeneren van glucose. Toevoeging van isosorbide verhoogt de $T_{g}$ van PET, maar het materiaal wordt minder kristallijn als gevolg van de introductie van onregelmatigheden in de polymeerketen.

\subsection{PEF}

Naast de productie van biotereftaalzuur wordt ook gewerkt aan vervanging van tereftaalzuur door 2,5-furaandicarbonzuur (FDCA) voor de productie van PEF (polyethyleenfuraandicarbonzuur). FDCA kan zowel via chemische routes als via fermentatie worden gesynthetiseerd vanuit suikers De productie van FDCA uit suikers lijkt op dit moment goedkoper dan de productie van biotereftaalzuur. 
Omdat FDCA een andere moleculaire structuur heeft dan tereftaalzuur, heeft PEF andere eigenschappen dan PET. Zo zijn de gerapporteerde barrière-eigenschappen van PEF voor zowel $\mathrm{CO}_{2}$, water als zuurstof significant beter dan die van PET. Ook is PEF beter UVstabiel.

FDCA en PEF worden nog niet op grote schaal geproduceerd. De bouw van de eerste industriële FDCA fabriek in Antwerpen (België) door Synvina (J V van Avantium en BASF) met een capaciteit van 50 kton per jaar is aangekondigd, maar ook al vertraagd. Minimaal 2 andere bedrijven/consortia werken ook aan de commercialisatie van PEF en FDCA gerelateerde materialen. Zo heeft Corbion een fermentatief proces ontwikkeld voor de productie van FDCA en werken ADM en DuPont aan de productie van PTF (polytrimetyleenfuranoaat), een combinatie van FDCA en biobased 1,3-propaandiol.

\subsection{BioPBS}

PBS (polybutyleen succinaat) is een polyester die wordt geproduceerd via copolymerisatie van barnsteenzuur en 1,4-butaandiol. Barnsteenzuur en 1,4-butaandiol worden op dit moment voornamelijk vanuit petrochemische grondstoffen geproduceerd en zijn zogenaamde C4-chemicaliën. C4-chemicaliën zijn relatief duur en barnsteenzuur kan goedkoper worden geproduceerd via biologische routes zoals de fermentatie van glucose. Omdat tijdens deze fermentatie $\mathrm{CO}_{2}$ wordt ingebouwd is barnsteenzuur milieutechnisch een zeer interessante biobased bouwsteen. Diverse grote bedrijven en consortia werken aan de ontwikkeling en opschaling van de productie van biobased barnsteenzuur. Vanuit barnsteenzuur kan ook 1,4-butaandiol worden geproduceerd en daarmee is de productie van $100 \%$ biobased PBS mogelijk. Succesvolle implementatie en opschaling van nieuwe technologieën kunnen leiden tot een significante prijsdaling van PBS. En inmiddels is 50\% biobased PBS commercieel beschikbaar.

PBS is biologisch afbreekbaar en composteerbaar. Wat betreft de mechanische eigenschappen lijkt PBS op polypropyleen (PP) en high density polyethyleen (HDPE). Ten opzichte van veel andere biopolymeren heeft PBS een hogere maximale gebruikstemperatuur (HDT) en is het veel taaier. Daarnaast kristalliseert het snel waardoor het uitstekend is te verwerken via spuitgiettechnologiëen. Door de introductie van andere monomeren (zoals melkzuur, tereftaalzuur of adipinezuur) kunnen de eigenschappen van PBS-polymeren worden aangepast. Zo is PBSA veel flexibeler dan PBS en breekt het sneller af in het milieu.

PBS-polymeren zijn goede componenten voor biobased blends met andere polymeren zoals PLA, polyhydroxyalkanoaten (PHA) of thermoplastisch zetmeel (TPS). De huidige wereldwijde PBS-productie is ongeveer 40 kton per jaar en er zijn ambitieuze plannen voor groei. 


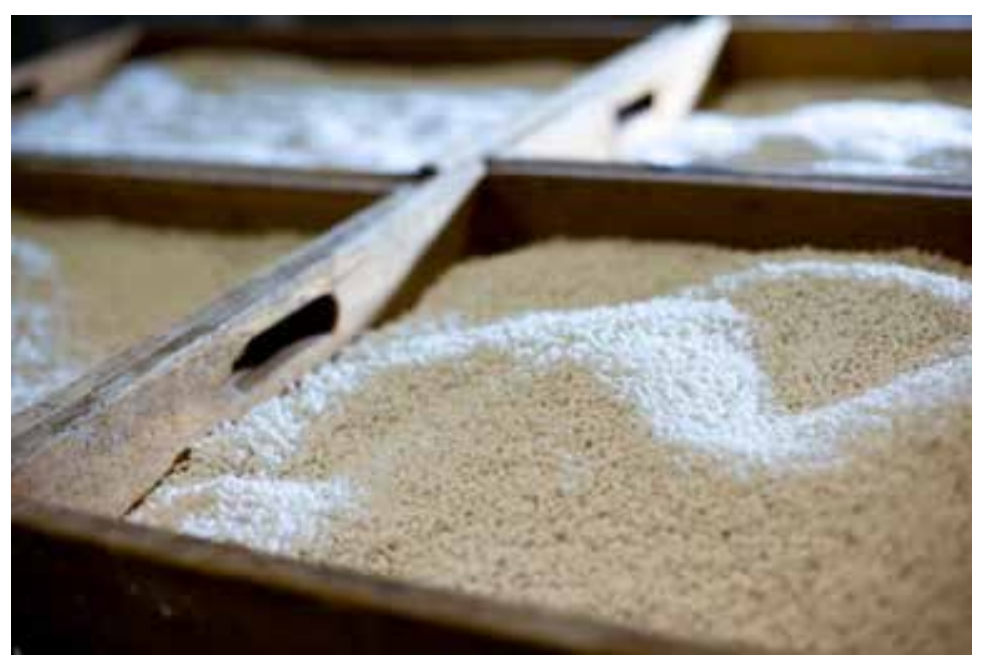

Drogen van bioplastic korrels

\subsection{Biopolyamides}

Polyamides, beter bekend onder de generieke naam nylons, vormen een belangrijke klasse van hoogwaardige kunststoffen (engineering plastics). Ze worden geproduceerd via polycondensatie van een di-zuur en een di-amine, of via ringopeningpolymerisatie van een lactam (cyclische verbinding met een amide groep). Polyamides worden genoemd naar het aantal koolstofatomen van elk van de monomeren. De meest bekende polyamide is PA 6,6 waarbij de eerste 6 staat voor de 6 koolstofatomen van het diamine (1,6-hexaandiamine) en de tweede 6 voor de 6 koolstofatomen van het dicarbonzuur (adipinezuur). PA 6 wordt gemaakt via ringopeningpolymerisatie van caprolactam dat ook 6 koolstofatomen heeft.

Polyamides kunnen biobased worden gemaakt door het gebruik van monomeren (dizuur en di-amine, lactam) uit hernieuwbare bronnen. Een bekend voorbeeld van een biobased polyamide is PA 11 waarvan de grondstoffen worden gemaakt uit ricinusolie (castor- of wonderolie welke wordt gewonnen uit de tropische plant Ricinus communis). PA 11 is een hoogwaardige kunststof die wordt toegepast in, onder andere, de automobielindustrie en olie- en gaswinning. Het materiaal is al 70 jaar op de markt en van oudsher biobased.

Verschillende grote kunststofproducenten uit Europa, Amerika en Japan brengen polyamides op de markt die (gedeeltelijk) biobased zijn. Voorbeelden zijn PA 11, PA 6,10 , PA 4,10 en PA 10,10. Opvallend is dat vrijwel alle biobased bouwstenen voor deze biopolyamides worden geproduceerd vanuit castorolie. Het commerciële succes van deze 
materialen en de polyamides die nog in ontwikkeling zijn wordt grotendeels bepaald door de prijs waartegen de biobased monomeren geproduceerd kunnen worden.

\subsection{BioPE}

Polyethyleen (PE) is de meest gebruikte kunststof ter wereld met een marktaandeel (over alle thermoplastische kunststoffen) van bijna 30\%. In Brazilië wordt biobased PE geproduceerd in een fabriek met een capaciteit van 200 kton per jaar.

BioPE is qua eigenschappen identiek aan petrochemisch PE, maar wordt geproduceerd uit ethyleen dat uit bioethanol wordt gemaakt in plaats van aardolie. In Brazilië wordt op grote schaal bioethanol geproduceerd via de fermentatie van suikers uit suikerriet. Bioethyleen kan qua kosten in principe concurreren met ethyleen gemaakt uit aardolie. Toch wordt bioPE verkocht tegen een meerprijs van ca. 20-30\%. Bedrijven lijken bereid deze meerprijs te betalen, alleen omdat het materiaal biobased en duurzamer is. Grote verpakkingsproducten en A-merken van voedsel en cosmetica hebben bioPE inmiddels geïntroduceerd in hun verpakkingsproducten. Deze verpakkingen variëren van folieverpakkingen, flacons en tubes tot drankenkartons waarin een $\mathrm{PE}$-coating verwerkt is.

\subsection{Biobased polycarbonaat}

Sinds enige tijd wordt (gedeeltelijk) biobased polycarbonaat op de markt gebracht. Het materiaal is gebaseerd op isosorbide (uit sorbitol) en heeft een biobased content van ongeveer $60 \%$. Het materiaal is niet identiek aan polycarbonaat uit fossiele grondstoffen. Een voordeel van biobased polycarbonaat zijn de uitstekende eigenschappen ten aanzien van taaiheid en krasvastheid en daarbij uitstekende optische eigenschappen en UV-stabiliteit. Toepassingen zijn te vinden in de automobielindustrie (interieur en exterieur) en in elektronica toepassingen (touchscreens).

\subsection{Biobased thermoplastische elastomeren}

Thermoplastische elastomeren (TPE's) zijn bij gebruikstemperaturen (kamertemperatuur) elastisch zoals rubbers, maar kunnen bij hogere temperaturen verwerkt worden zoals thermoplasten. Door toepassing van biobased bouwstenen kunnen thermoplastische elastomeren (gedeeltelijk) biobased gemaakt worden. De biobased content van commercieel beschikbare biobased TPE's varieert globaal tussen 40 en meer dan $90 \%$. Doorgaans is het gehalte biobased van de "zachtere" TPE" typen lager dan die van hardere TPE typen. De materialen zijn verkrijgbaar via meerdere producenten en worden bijvoorbeeld toegepast in schoenzolen. 


\subsection{Overige ontwikkelingen}

Door de industrie wordt momenteel op brede schaal gewerkt aan de ontwikkeling en opschaling van andere thermoplastische polymeren op basis van biobased bouwstenen. Zo kan op basis van biobased etheen (uit bioethanol) een breed scala aan materialen gemaakt worden. Plannen voor de productie van biobased bulk polymeren zoals biobased polypropyleen (PP) en biobased polyvinylchloride (PVC) uit bioethyleen zijn voorlopig uitgesteld maar wellicht worden deze in de toekomst toch weer opgepakt. Technologisch gezien kan ieder petrochemisch monomeer worden geproduceerd uit biologische grondstoffen. De traditionele petrochemische kunststoffenindustrie kan worden vervangen door een biobased kunststoffen industrie, simpelweg via substitutie. Toch zal substitutie niet de enige route worden richting biobased kunststoffen. Dit heeft verschillende redenen.

Om qua prijs beter te kunnen concurreren met petrochemische kunststoffen worden nieuwe kunststoffen ontwikkeld die eenvoudiger, en dus goedkoper, kunnen worden geproduceerd op basis van biologische grondstoffen. Voorbeelden zijn PLA uit melkzuur en PBS op basis van barnsteenzuur. Petrochemische bouwstenen kunnen worden vervangen door vergelijkbare maar niet identieke monomeren omdat deze via productie uit biologische grondstoffen goedkoper zijn zoals FDCA ten opzichte van tereftaalzuur. Belangrijk is de conclusie uit een studie naar duurzaamheid van biobased producten dat het duurzamer is biobased kunststoffen te produceren op een wijze waarbij de oorspronkelijke structuur van de gebruikte grondstoffen zoveel mogelijk is behouden ${ }^{3}$. Concreet houdt dit in dat het duurzamer, maar waarschijnlijk op de lange termijn ook economisch rendabeler, is om suikers te gebruiken voor de productie van PLA dan voor de productie van bioPE (grotere reductie van energiegebruik en broeikasgasemissies). Het succes en de groei van "gecertificeerd" hernieuwbare kunststoffen zal afhankelijk zijn van de beschikbaarheid en prijs van hernieuwbare grondstoffen die geschikt zijn om bij te mengen in naftakrakers.

Tenslotte is er een groep kunststoffen die geproduceerd wordt uit monomeren die voor de mens schadelijk zijn zoals bisfenol-A in polycarbonaat. Omdat de kans groot is dat op termijn dit soort monomeren en kunststoffen slechts beperkt mogen worden toegepast, wordt niet gewerkt aan identieke verbindingen op basis van biologische grondstoffen.

\footnotetext{
${ }^{3}$ Duurzaamheid van biobased producten; Energiegebruik en broeikasgasemissie van producten met suikers als grondstof, Harriëtte Bos, Sjaak Conijn, Wim Corré, Koen Meesters en Martin Patel, 2011, uit de reeks 'Groene Grondstoffen'
} 


\section{Thermoharders op basis van biobased monomeren}

\subsection{Introductie}

Thermoharders zijn polymeren waarvan de ketens onderling verknoopt zijn. Door monomeren te gebruiken met meer dan 2 functionele groepen wordt de mogelijkheid gecreëerd om verbindingen of crosslinks te vormen tussen de ketens. Ook via onverzadigde verbindingen in de polymeerketen kunnen crosslinks geïntroduceerd worden. De hoeveelheid van deze crosslinks (crosslinkdichtheid) is van invloed op de eigenschappen van het materiaal. Na uitharding (vernetting) kunnen thermoharders niet meer vloeien, dus niet meer verwerkt worden in een andere vorm zoals thermoplasten. Net als voor de ontwikkeling van thermoplasten uit biobased monomeren geldt dat er twee mogelijke strategieën zijn voor de ontwikkeling van thermoharders of thermoset materialen:

Vervanging van petrochemische bouwstenen door biobased bouwstenen

Deze aanpak heeft als voordeel dat de materialen een hoger gehalte aan biobased kunnen krijgen zonder veel aanpassingen in de productie en verwerking. Nadeel van deze aanpak is dat er voor diverse reactieve groepen geen biobased alternatief is. Het is daardoor moeilijk om via deze aanpak een $100 \%$ biobased systeem te ontwikkelen.

Productie van nieuwe thermoharders op basis van biobased grondstoffen

Hierbij wordt onderzocht hoe zo optimaal mogelijk gebruik gemaakt kan worden van (reactieve) bouwstenen die in de natuur voorkomen, of eenvoudig gemaakt kunnen worden op basis van natuurlijke bouwstenen. Nadeel van deze route is dat nieuwe harssystemen en uithardingscondities geïntroduceerd moeten worden, met voor materiaalverwerkers bijkomende kosten in de aanpassing van apparatuur en infrastructuur.

\subsection{Polyurethanen}

Polyurethanen vormen een familie van over het algemeen thermohardende polymeren met een breed scala aan eigenschappen en toepassingen. Polyurethanen worden gevormd door polymerisatie van polyolen (verbinding met twee of meer hydroxylgroepen) met ( $\mathrm{di}^{-}$) isocyanaten (verbinding met twee of meer isocyanaat groepen). De uiteindelijke eigenschappen van polyurethanen worden bepaald door de structuur van de gebruikte polyolen en isocyanaten. Huidige toepassingen variëren van flexibele- en harde schuimen tot coatings, lijmen, kitten en elastomeren. 
Ontwikkelingen op het gebied van biobased polyurethanen richten zich voornamelijk op biobased polyolen. Diverse grote internationale producenten brengen biobased polyolen op de markt die specifiek geschikt zijn voor toepassing in polyurethanen:

- Polyolen uit natuurlijke oliën (ricinusolie of sojaolie) voor diverse polyurethaan applicaties

- 1,3-propaandiol (via fermentatie van suikers) voor de productie van polyetherpolyolen

- Barnsteenzuur of adipinezuur (via fermentatie van suikers) voor de productie van polyesterpolyolen

- Suikerpolyolen voor met name de productie van polyolen voor harde polyurethaanschuimen

Oliën zijn esters van glycerine (of glycerol) en vetzuren. Ricinusolie is een belangrijke grondstof voor de productie van biobased polyolen omdat het reactieve hydroxylgroepen bevat. Het vetzuur ricinolzuur heeft in het midden van de koolstofketen een dubbele binding en daarnaast een hydroxylgroep. Door deze reactiviteit polymeriseert ricinusolie gemakkelijk en is het zeer geschikt als ingrediënt voor verven, kleurstoffen, coatings en inkten. Daarnaast wordt het vanwege de hydroxylgroepen toegepast in polyurethanen.

Aan de ontwikkeling van polyolen uit andere, mogelijk goedkopere, plantaardige oliën (Natural Oil Polyols, NOP's), zoals soja-, zonnebloem- of koolzaadolie wordt gewerkt. Het

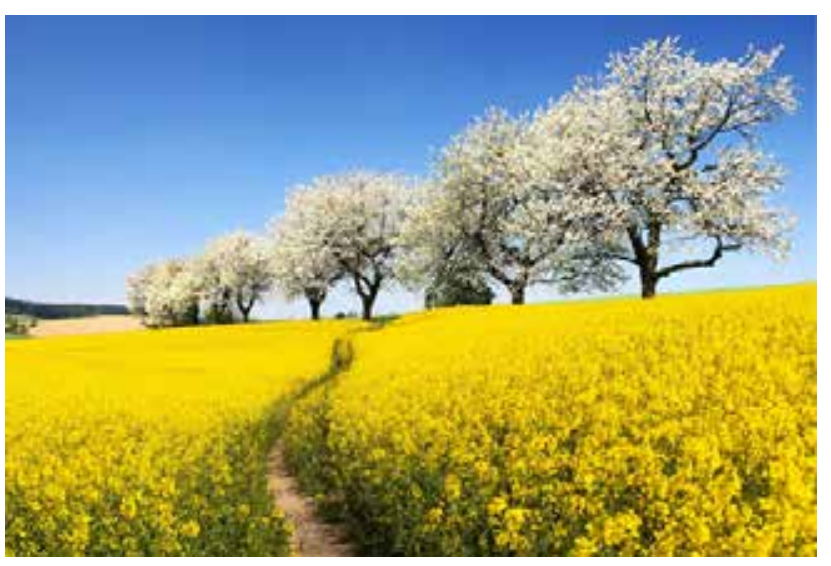
aantal mogelijkheden om polyolen te produceren uit plantaardige olie is bijna onbegrensd en de belangrijkste onderzoeksvragen op dit moment zijn:

- Hoe kunnen NOP's worden geproduceerd met de juiste hoeveelheid reactiviteit?

- Hoe kan ringvorming, die aanleiding kan geven tot onaangename geuren, worden voorkomen?

Ondertussen worden NOP's al op grote schaal geproduceerd en toegepast. Doorgaans is alleen het polyoldeel van de polyurethaan (deels) biobased en varieert het biobased gehalte tussen de $10 \%$ en $70 \%$ afhankelijk van de specifieke toepassing. Sinds enige 
jaren zijn er biobased isocyanaten op de markt waarmee het mogelijk is $100 \%$ biobased polyurethanen te maken. Een voorbeeld van een biobased di-isocyanaat is pentamethyleen di-isocyanaat (PDI) als vervanger voor hexamethyleen di-isocyanaat. Naar schatting is het marktvolume van biobased polyurethanen vergelijkbaar met dat van bioPET.

\subsection{Epoxyharsen}

Epoxyharsen (of epoxies) vormen een familie van thermohardende kunststoffen die voornamelijk worden gebruikt voor beschermende coatings, in lijmen maar ook in composieten. De wereldwijde markt voor epoxyharsen bedraagt ongeveer 1,5 miljoen ton per jaar. Bijna $75 \%$ van de epoxyharsen wordt geproduceerd op basis van bisphenolA en epichloorhydrine.

Toepassing van biobased grondstoffen in epoxyharsen heeft zich in eerste instantie gericht op geëpoxideerde natuurlijke verbindingen. Plantaardige oliën met dubbele bindingen (zoals soja-, lijnzaad- of ricinusolie) kunnen worden geëpoxideerd. De reactiviteit en daarmee de uiteindelijke crosslinkdichtheid in het product zal afhangen van het aantal epoxide groepen. Geëpoxideerde plantaardige oliën zijn op grote schaal beschikbaar omdat ze ook worden gebruikt als weekmakers en stabilisatoren voor PVC en in lakken en coatings. Sojaolie heeft als voordeel dat het goedkoop is. Om tot harsen met goede eigenschappen te komen worden naast epoxy-groepen vaak ook maleïneen/ of acrylaat groepen geïntroduceerd. Cardanol olie (uit Cashew Nut Shell Liquid) bevat natuurlijke fenol groepen en wordt gebruikt voor de synthese van "vernetters" voor epoxyharsen. Ook geëpoxideerde cardanol olie is commercieel beschikbaar.

Epoxyharsen met een biobased gehalte van ca. 20\% worden momenteel geproduceerd uit glycerol, een bijproduct van de productie van biodiesel. Deze harsen bevatten epichloorhydrine die gemaakt is uit glycerol.

Tenslotte wordt gewerkt aan de vervanging van de toxische componenten van epoxies (bisphenol-A) en toepassing van amine-gefunctionaliseerde biobased bouwstenen. Hernieuwbare grondstoffen voor bisphenol-A vervangers zijn o.a. furanen, pijnhars (rosin), lignine, itaconzuur en isosorbide.

\subsection{Onverzadigde polyesters}

Onverzadigde polyesters of unsaturated polyesters (UP) zijn polyesters die dubbele (of onverzadigde) verbindingen bevatten. UP-harsen zijn vaak vloeibare mengsels van onverzadigde polyesters met styreen, waarbij styreen fungeert als reactief oplosmiddel. Het resultaat is een materiaal met uitstekende eigenschappen voor toepassing in coatings, lijmen of composieten. Net als in thermoplastische polyesters kunnen ook voor onverzadigde polyesters biobased monomeren worden toegepast. 
Op dit moment is een aantal deels biobased producten (tot ca. 70\%) commercieel beschikbaar. In deze harsen wordt gebruik gemaakt van biobased monomeren zoals isosorbide, itaconzuur, castorolie derivaten en barnsteenzuur. Onderzoek richt zich voornamelijk op het vervangen van de reactieve verdunner styreen in UP-harsen.

\subsection{Alternatieve vetzuur gebaseerde reactieve systemen}

Alkydharsen zijn belangrijke voorbeelden van uithardende systemen. Alkydharsen kwamen in de jaren '20 op de markt als hoogwaardige coatings. Chemisch gezien zijn het thermoharders en worden ze geproduceerd door copolymerisatie van polyolen, organische zuren en plantaardige oliën. Het percentage biobased grondstoffen van commercieel beschikbare alkydharsen is niet bekend; in ieder geval is de plantaardige olie biobased en dit gehalte kan oplopen tot $60 \%$.

Het gebruik van plantaardige oliën en vetzuren is een inspiratie voor de productie van bioharsen met een hoog gehalte aan biobased grondstoffen. Nieuwe reactieve systemen zijn harsen op basis van geëpoxideerde plantaardige oliën en polycarboxylzuuranhydrides van natuurlijke oorsprong. Het gehalte biobased grondstoffen van dit harssysteem kan oplopen tot $96 \%$. Het harssysteem is minder reactief vergeleken met bijvoorbeeld epoxy- en polyesterharsen en moet om een economisch rendabel gebruik mogelijk te maken bij hogere temperaturen $\left(>100{ }^{\circ} \mathrm{C}\right)$ worden uitgehard. Ter vergelijking: bij $100{ }^{\circ} \mathrm{C}$ duurt de uitharding enkele uren, bij $190{ }^{\circ} \mathrm{C} 1$ minuut.

Een alternatief systeem gaat uit van geacryleerde geëpoxideerde oliën die worden uitgehard met methacrylzuur, eventueel in combinatie met styreen. Het voordeel van dit systeem is dat het een relatief lage viscositeit heeft, maar het is nog steeds minder reactief dan epoxy- en UP-harsen en moet bij verhoogde temperaturen $\left(90^{\circ} \mathrm{C}\right)$ worden uitgehard.

\subsection{Furaanharsen}

Furanen zijn ringstructuren die kunnen worden geproduceerd via dehydratatie van suikerverbinding zoals glucose en fructose. Op basis van furfurylalcohol worden harsen geproduceerd die vergelijkbaar zijn met fenolharsen. Deze harsen worden gebruikt in de gieterij-industrie en in plaatmaterialen (zoals MDF). Furaanderivaten, met name 5-hydroxymethylfurfural (HMF), zijn in hernieuwde belangstelling gekomen door ontwikkelingen op het gebied van de productie van biobrandstoffen (biodiesel, bioethanol).

In het vorige hoofdstuk is daarnaast al aangegeven dat furanen een veelbelovende familie van verbindingen is die aromatische bouwstenen in (thermoplastische) polymeren kan vervangen. Met name 2,5-furaandicarbonzuur (FDCA) is uitgebreid onderzocht als substituut voor bijvoorbeeld tereftaalzuur in polyesters en polyamiden. 


\section{Biobased plastics op basis van natuurlijke polymeren}

\subsection{Introductie}

Plastics uit polymeren van natuurlijk oorsprong zijn polymeren die direct worden geëxtraheerd en gewonnen uit biomassa zoals hout, maïs, tarwe, rijst en aardappels. Voorbeelden hiervan zijn zetmeel en cellulose. Plastics gemaakt door micro-organismen zijn plastics die worden geproduceerd door bacteriën, gisten of planten. Beide typen plastics zijn biobased plastics op basis van natuurlijke polymeren en worden in dit hoofdstuk beschreven.

\subsection{Zetmeel}

\subsubsection{Inleiding}

Zetmeel dient als voedselopslag in planten en is één van de meest voorkomende natuurlijke organische verbindingen. In Europa wordt 50\% van de totaal beschikbare hoeveelheid zetmeel gebruikt voor levensmiddelen en diervoeders, $17 \%$ voor de productie van bioethanol en $33 \%$ voor andere non-food producten. Veruit de belangrijkste industriële toepassing van zetmeel is in de golfkarton- en papierindustrie voor het verlijmen van karton en ter verbetering van de bedrukbaarheid van papier. Andere industriële toepassingen zijn in de textiel- en lijmstoffenindustrie, in de farmacie en in cosmetica.

\subsubsection{Grondstoffen}

Zetmeel is een koolhydraat bestaande uit een groot aantal glucose eenheden. Zetmeel kent twee verschillende chemische vormen: het lineaire amylose polymeer en het vertakte amylopectine polymeer. De verhouding amylose/amylopectine in zetmeel verschilt per plantsoort. Zetmeel wordt gewonnen uit gewassen zoals aardappelen, maïs, tarwe, rijst en cassave en is een relatief goedkope grondstof. De prijs van zetmeel varieert tussen $€ 200$ en $€ 600$ per ton waardoor zetmeel goedkoper is dan ruwe olie. Ter vergelijking, bij circa $\$ 100$ per vat kost ruwe olie ongeveer $€ 530$ per ton.

\subsubsection{TPS Productie}

Zuiver zetmeel (natief zetmeel) is echter geen thermoplastisch materiaal. Het kan niet in de smelt worden verwerkt zonder toevoeging van additieven of zonder chemische modificatie omdat het degradeert voordat het smelt. Hierdoor liggen de prijzen van commercieel beschikbare zetmeelplastics vrij hoog, tussen $€ 1,5$ en $€ 4$ per kilo.

De meest gebruikte methode voor de productie van thermoplastisch zetmeel (Thermoplastic Starch, TPS) is de verwerking van natief zetmeel met een geschikte weekmaker zoals water of glycolen in een extruder. Door verhoogde temperaturen, 
voldoende afschuiving en de aanwezigheid van weekmakers verandert de fysische structuur van natief zetmeel en wordt het zetmeel thermoplastisch verwerkbaar.

Andere methoden die worden gebruikt om zetmeel gebaseerde plastics te produceren zijn (gedeeltelijke) fermentatie, chemische modificatie en mengen of blenden met andere organische verbindingen. De bron (plantensoort) van het zetmeel heeft via de samenstelling (amylose, amylopectine) invloed op de eigenschappen van de plastics. TPS wordt vaak gemengd met andere biobased polymeren om diverse eigenschappen te verbeteren en het toepassingsgebied uit te breiden. Voor dit doel kunnen copolyesters zoals polybutyleen adipaat tereftalaat (PBAT), polycaprolacton, PLA, PBS, polyhydroxyalkanoaat (PHA) en celluloseacetaat gebruikt worden in combinatie met de benodigde additieven.

Het zetmeelgehalte in dergelijke TPS-blends varieert tussen $30 \%$ en $70 \%$. Omdat veel commercieel verkrijgbare TPS-blends niet-hernieuwbare of gedeeltelijk hernieuwbare polymeren bevatten zijn deze materialen vaak niet $100 \%$ biobased.

\subsubsection{Verwerking}

TPS kan op dezelfde manier verwerkt worden als traditionele thermoplastische polymeren met behulp van verwerkingstechnieken zoals extrusie, spuitgieten, folieblazen, sheetextrusie (en thermovormen) en extrusieschuimen. Verwerkingstemperaturen variëren tussen $120^{\circ} \mathrm{C}$ en $180^{\circ} \mathrm{C}$. TPS moet niet worden gedroogd voor verwerking, water is essentieel voor de thermoplastische verwerkbaarheid van het materiaal.

\subsubsection{Eigenschappen}

De mechanische eigenschappen van TPS kunnen variëren van flexibel (vergelijkbaar met polyethyleen; E-modulus $500 \mathrm{MPa}$ ) tot stijf (vergelijkbaar met polystyreen,

E-modulus $3000 \mathrm{MPa}$ ). Met behulp van vulmiddelen (zoals krijt of talk) en natuurlijke vezels (zoals vlas) is een verdere variatie van eigenschappen van TPS mogelijk.

Bijzondere eigenschappen van TPS zijn de gasbarrière eigenschappen en antistatisch gedrag. Thermoplastisch zetmeel heeft een relatief lage $\mathrm{CO}_{2}$ - en $\mathrm{O}_{2}$-doorlaatbaarheid en een hoge waterdampdoorlaatbaarheid en is dan ook bijzonder geschikt voor specifieke voedselverpakkingen. Een nadeel van TPS in verpakkingen is dat folies niet transparant maar translucent zijn; dat wil zeggen enigszins melkachtig, maar als het product tegen de folie aandrukt is het wel goed zichtbaar. Zetmeel is wateroplosbaar en producten gemaakt van TPS vallen langzaam uit elkaar in water. Deze eigenschap kan worden benut in toepassingen waar oplosbaarheid in water gewenst is. Voor veel toepassingen is de verbetering van de watervastheid echter gewenst. Dit is goed mogelijk door gebruik te maken van blends of TPS te verwerken in meerlaagsfolies. Op TPS-gebaseerde materialen degraderen zeer snel in diverse milieus, maar daarbij is de blend- 
samenstelling wel van groot belang. De materialen zijn niet alleen composteerbaar in industriële composteringsinstallaties maar ook thuiscomposteerbaar en afbreekbaar in de bodem.

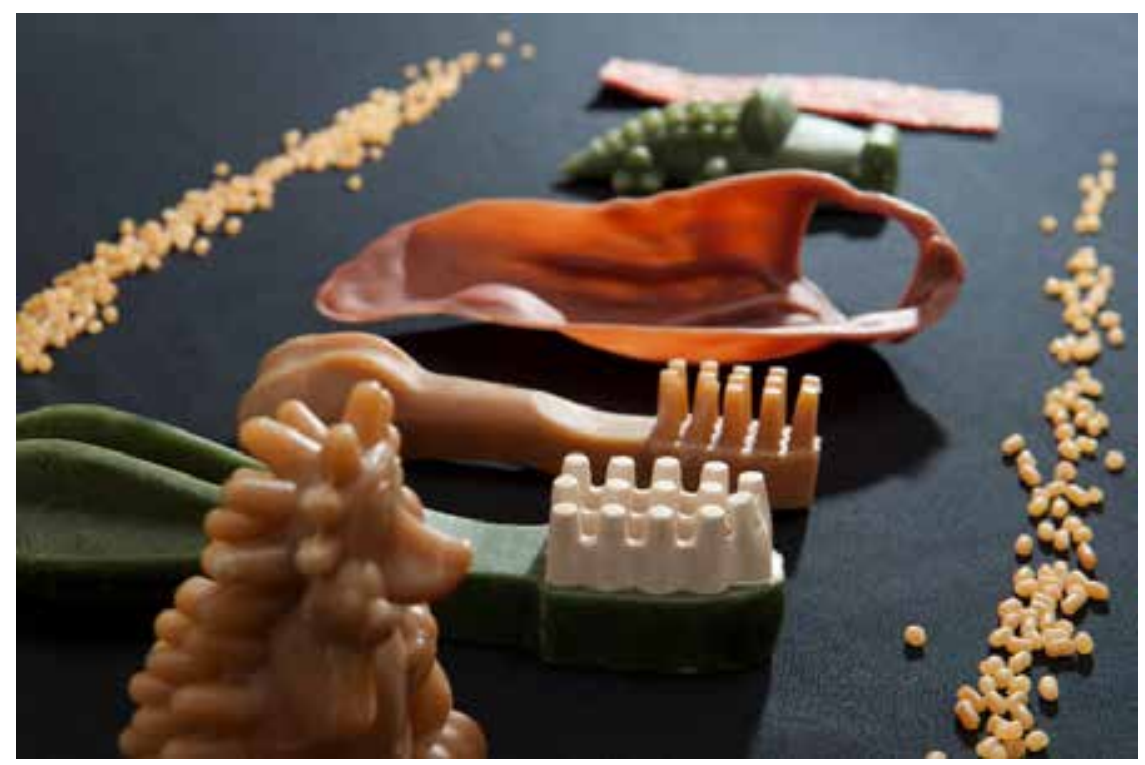

Vegetarisch hondensnacks op basis van TPS (Paragon Pet chews)

\subsubsection{Toepassingen}

Een belangrijke toepassing is loose-fill schuimen. Tijdens de productie van schuimchips wordt het water in zetmeel gebruikt als blaasmiddel. Een andere belangrijke toepassing voor TPS-blends zijn folies voor zakken zoals boodschappentassen en afvalzakken voor groenafval. TPS wordt ook veel toegepast in (catering) disposables zoals schuimbakjes en bestek. In deze toepassingen is de biologische afbreekbaarheid een groot voordeel en, in combinatie met het hoge biobased gehalte, de belangrijkste reden voor toepassing van TPS.

Voorbeelden waarbij gebruik wordt gemaakt van de specifieke eigenschappen van TPS zijn het verpakken van voedsel, waarbij gebruik gemaakt wordt van de gasbarrière eigenschappen, en eetbare producten op basis van TPS. Via spuitgieten wordt TPS verwerkt tot vegetarische hondensnacks die kunnen worden gevormd tot botten, tandenborstels, egeltjes etc. In de land- en tuinbouw worden plantenpotten, bindstrips en onkruid werende folies (mulch films) vaak gemaakt van TPS-blends. Reductie van arbeidskosten, omdat verwijdering van de plastics uit landbouwafval of land onnodig 
wordt, en reductie van afvalkosten maken het gebruik van TPS-materialen prijscompetitief in vergelijking met niet-afbreekbare plastics.

Met hun uiteenlopende toepassingen behoren TPS materialen tot één van de meest gebruikte biobased plastics met een productiecapaciteit van meer dan 300 kton/jaar.

\subsubsection{Ontwikkelingen}

Toekomstige ontwikkelingen op het gebied van TPS-gebaseerde materialen zijn de ontwikkeling van $100 \%$ biobased blends en materialen die geschikt zijn voor toepassingen waar meer eisen aan verbonden zijn. Goedkopere blends kunnen worden gemaakt door gebruik te maken van meel in plaats van (gezuiverd) zetmeel en door verhoging van het zetmeelgehalte in TPS-blends.

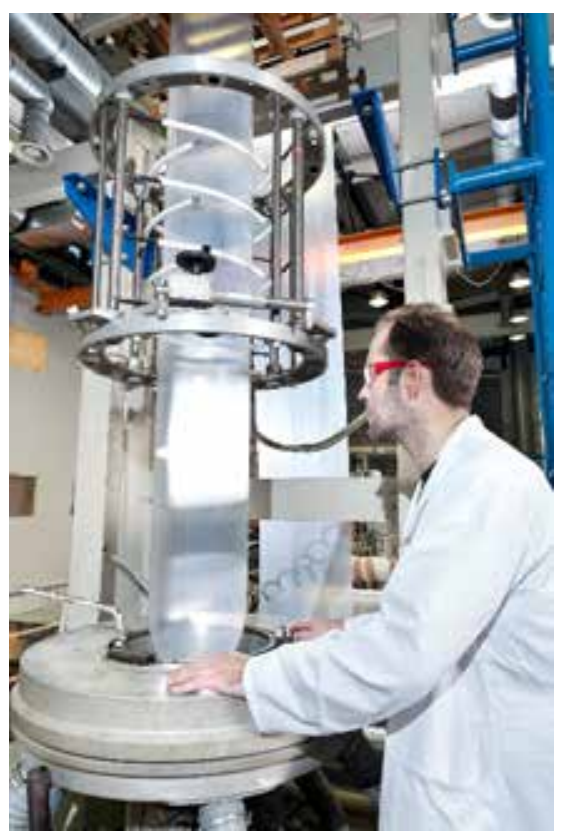

Productie van zetmeelgebaseerde folie

\subsection{Cellulose}

\subsubsection{Inleiding}

Cellulose is het meest voorkomende polymeer op aarde. Ongeveer 33\% van al het plantmateriaal is cellulose. Net als zetmeel is cellulose een koolhydraat dat bestaat uit een groot aantal glucose-eenheden, met als belangrijkste verschil dat cellulose semikristallijn is. Door deze kristalliniteit heeft cellulose een hoog smeltpunt en is daardoor niet thermoplastisch verwerkbaar en niet oplosbaar in gangbare oplosmiddelen. 
De grondstof voor de productie van biobased plastics op basis van cellulose is een zeer zuivere cellulose pulp (dissolving pulp). Deze pulp wordt hoofdzakelijk geproduceerd uit hout (cellulose gehalte 40-50\%) en katoen (cellulose gehalte 90\%).

De belangrijkste toepassingen van niet-thermoplastisch cellulose zijn vezels (rayon, viscose) en folies (cellofaan); deze cellulose materialen staan bekend als geregenereerde cellulose. Thermoplastische cellulosederivaten zoals celluloseacetaat worden hoofdzakelijk gebruikt in vezels voor textiel of sigarettenfilters. Echter, de belangstelling voor celluloseacetaten als biobased materiaal voor andere toepassingen neemt toe.

Om de verschillende typen cellulose polymeren goed te onderscheiden worden ze hier afzonderlijk beschreven.

\subsubsection{Geregenereerde cellulose}

Geregenereerde celluloses worden geproduceerd vanuit een oplossing en zijn niet verwerkbaar in de smelt. Traditionele productieprocessen gaan gepaard met het gebruik van vervuilende chemicaliën zoals koolstofdisulfide $\left(\mathrm{CS}_{2}\right)$. Ten aanzien van het milieuvriendelijk produceren van geregenereerde celluloses is veel vooruitgang geboekt. Daarbij zijn er nieuwe, milieuvriendelijker productiemethoden ontwikkeld zoals het Lyocell proces. Zowel de dure grondstof (dissolving pulp) als het productieproces (energie, chemicaliën) dragen bij aan de vrij hoge prijs van geregenereerde celluloses.

Viscose was, ter vervanging van katoen, in het begin van de vorige eeuw de meest voorkomende synthetische vezel. In de jaren zestig is met de ontwikkeling van nieuwe petrochemische vezels, zoals nylon en polyester, viscose in veel toepassingen verdrongen. In hoogwaardige toepassingen wordt viscose nog toegepast omdat het een vergelijkbaar comfort biedt en dezelfde eigenschappen heeft als natuurlijke vezels zoals zijde, wol, katoen en linnen. Viscose is ideaal in warme en vochtige klimaten. Het absorbeert vocht maar laat lichaamswarmte door.

Cellofaan folie wordt gebruikt voor verpakkingen, plakband en in een aantal industriële toepassingen zoals semipermeabel membraan in bepaalde batterijen. Hier is de hoge dimensiestabiliteit een groot voordeel ten opzichte van de meeste thermoplastische folies, evenals de goede resistentie tegen chemicaliën, oliën en vetten. Cellofaan heeft een uitstekende glans en transparantie, en is een stijf materiaal dat zich gemakkelijk laat vouwen waardoor het ideaal is voor snoepverpakking.

In nieuwe toepassingen wordt gebruik gemaakt van de biologische afbreekbaarheid van cellofaan en het feit dat het materiaal $100 \%$ biobased is. Vaak wordt cellofaan voorzien van een TPS-gebaseerde seallaag om het materiaal sealbaar te maken wat in veel toepassingen een vereiste is. Barrièrefolies met een uitstekende zuurstofbarrière zijn 
commercieel verkrijgbaar. Om deze barrière-eigenschappen te creëren wordt de cellofaan film met aluminiumoxide gemetalliseerd. Barrièrefolies op basis van cellofaan voldoen aan de EN13432 norm voor compostering.

Geregenereerde celluloses vormen veruit de grootste groep industrieel toegepaste biobased plastics met een wereldproductie van 3,5 miljoen ton per jaar. Door de focus op biobased materialen is er een hernieuwde belangstelling voor cellulose materialen omdat ze $100 \%$ biobased en biologisch afbreekbaar zijn. Ontwikkelingen waaraan gewerkt wordt zijn nieuwe, meer milieuvriendelijke processen voor de productie van geregenereerde cellulose en verlaging van de productiekosten. Men verwacht een groei van nieuwe producten op basis van cellofaanfolies vanwege de bioafbreekbaarheid van het materiaal.

\subsubsection{Thermoplastische celluloses}

Cellulose moet (intensief) chemisch gemodificeerd worden om thermoplastisch verwerkbaar te worden. Voorbeelden zijn cellulose-esters zoals nitrocellulose en cellulose-acetaat. Deze cellulose plastics behoren tot de oudste commercieel geproduceerde kunststoffen.

Cellulosenitraat of nitrocellulose werd aanvankelijk geproduceerd door behandeling van cellulose met salpeterzuur. De eerste bewegende beelden die in de bioscoop te zien waren werden getoond op films van cellulosenitraat. Dit gebeurt al lang niet meer omdat het materiaal zeer licht ontvlambaar is. Het wordt nog wel gebruikt in explosieven en in diverse lakken.

Celluloseacetaat is op dit moment het belangrijkste thermoplastisch verwerkbare cellulosederivaat met een wereldproductie van ca. 840 kton per jaar. Deze celluloseester wordt geproduceerd door het modificeren van dissolving pulp met azijnzuuranhydride. Andere voorbeelden van celluloseacetaten zijn celluloseacetaatbutyraat (CAB) en celluloseacetaat-propionaat (CAP). Hoewel celluloseacetaten hernieuwbaar zijn, zijn ze niet echt milieuvriendelijk vanwege hun energie- en chemicaliënverbruik tijdens de productie.

Celluloseacetaat is beschikbaar in substitutiegraden die variëren van 2,5 tot 3 van de 3 beschikbare $\mathrm{OH}$-groepen. Deze substitutiegraad heeft invloed op de biologische afbreekbaarheid en de oplosbaarheid van het materiaal. Cellulosediacetaat (substitutiegraad $\sim 2.5$ ) is een amorf en transparant polymeer met goede optische (mooie glans), mechanische en thermische eigenschappen. De mechanische eigenschappen van cellulosediacetaat zijn wat betreft stijfheid vergelijkbaar met polystyreen en wat betreft taaiheid met polycarbonaat. De $T_{g}$ van zuiver 
cellulosediacetaat is ca. $200{ }^{\circ} \mathrm{C}$. Daarmee heeft het een hoge maximale gebruikstemperatuur (HDT).

Celluloseacetaat kan worden verwerkt via conventionele technieken zoals spuitgieten, extrusie en thermovormen. Het polymeer is minder geschikt om verwerkt te worden in spuitgietmachines met een hot-runner systeem waar het polymeer langere tijd in gesmolten toestand verkeert. Om de verwerkbaarheid van het materiaal te verbeteren kunnen weekmakers worden toegevoegd. Veel gebruikte weekmakers zijn citraatesters zoals acetyltriethylcitraat en triethylcitraat, triacetine en diethylftalaat. Tijdens de verwerking kan thermische degradatie optreden, vooral bij hogere temperaturen.

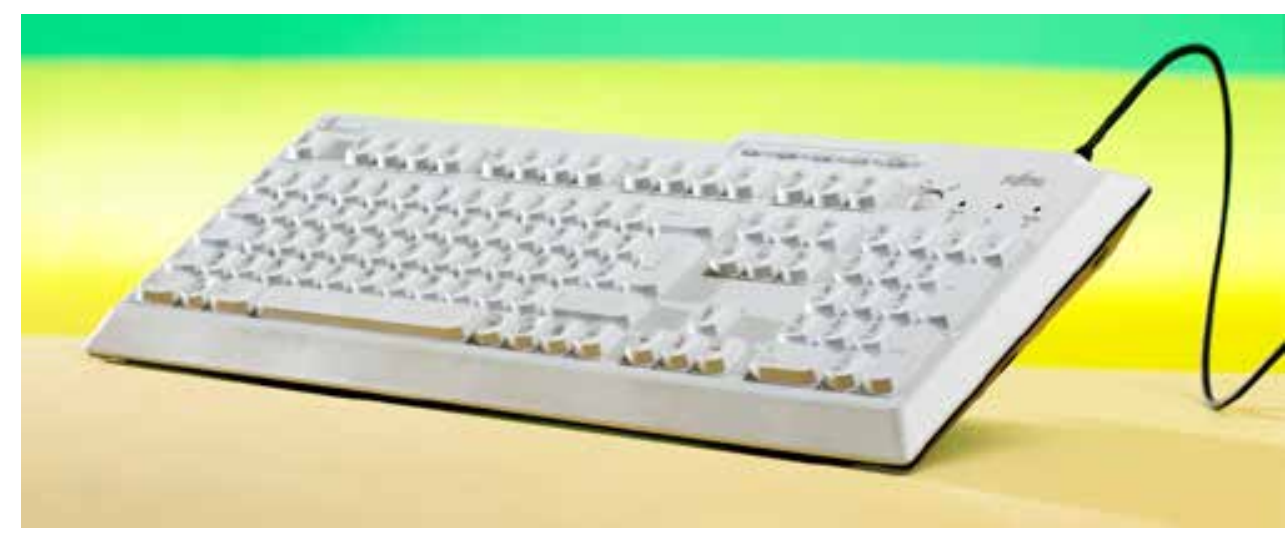

Toetsenbord gebaseerd op een celluloseacetaat compound (FKuR)

De belangrijkste toepassingen van celluloseacetaten zijn vezels voor de productie van sigarettenfilters (acetate tow) en textiel. In veel kunststof toepassingen is celluloseacetaat vervangen door petrochemische plastics. Cellulose-acetaten zijn nog steeds (of weer) terug te vinden in hoogwaardige toepassingen zoals tandenborstels, brilmonturen, handvatten voor schroevendraaiers, telefoons en toetsenborden. Voor deze toepassingen is het glossy uiterlijk en de prettige grip een groot voordeel.

Andere toepassingen zijn in lenzen, displays, decoratieve elementen (voor bijvoorbeeld de auto-industrie) en verpakkingen. Celluloseacetaat is door de goede hittebestendigheid een van de weinige plastics die gebruikt kan worden in combinatie met hete vloeistoffen of in de magnetron. Ook wordt celluloseacetaat nog toegepast in artikelen voor eenmalig gebruik zoals messen, lepels, vorken, borden en kopjes.

Het grootste nadeel van cellulose plastics is de hoge marktprijs van meer dan $€ 4$ per kilo en dit belemmert grootschalige toepassingen. Nieuwe ontwikkelingen op het gebied van celluloseacetaten richten zich op het maken van blends waarbij de goede 
eigenschappen van celluloseacetaten (hittebestendigheid en taaiheid) goed van pas komen. Ook wordt er gewerkt aan het toepassen van goedkopere vulmiddelen waarmee een aanzienlijke kostenreductie gerealiseerd kan worden.

\subsection{Biobased polymeren uit micro-organismen}

\subsubsection{Inleiding}

Wanneer het over polymeren gaat die worden geproduceerd door micro-organismen gaat de meeste aandacht uit naar polyhydroxyalkanoaten (PHA's), maar ook cellulose kan worden geproduceerd door micro-organismen. Deze microbiële cellulose vindt vanwege de hoge prijs en zuiverheid haar toepassing in niches zoals verbandmiddelen. PHA's blijven het meest aansprekende voorbeeld omdat ze een familie van polyesters vormen met een breed scala aan eigenschappen en toepassingen.

Polyhydroxyalkanoaten zijn lineaire alifatische polyesters. In principe kunnen veel polyesters met een zeer brede variatie in eigenschappen worden geproduceerd. Meer dan honderd verschillende monomeereenheden zijn geïdentificeerd als mogelijke bestanddelen van PHA's.

\subsubsection{Productie}

PHA's kunnen worden geproduceerd door verschillende bacteriën, gisten of planten. Planten en gisten moeten daarvoor altijd genetisch worden gemodificeerd. Voorbeelden van micro-organismen voor de productie van PHA's zijn Alcaligenes eutrophus of Bacillus megaterium. Als voedingsbron kunnen glucose, zetmeel, vetzuren of plantaardige oliën worden gebruikt.

Tijdens het productieproces is het van belang dat de micro-organismen zich eerst vermenigvuldigen om vervolgens te worden aangezet om PHA's te maken. De opbrengst varieert tussen de 30 en $80 \%$ op basis van drooggewicht van het micro-organisme.

Het door de micro-organismen efficiënt omzetten van voedingsstoffen naar PHA's en vervolgens de extractie van PHA zijn de belangrijkste stappen in het productieproces. $\mathrm{Er}$ moet nog veel onderzoek worden gedaan om deze stappen efficiënter en daarmee PHA's goedkoper te maken.

\subsubsection{Verwerking}

PHA's kunnen worden verwerkt met behulp van conventionele verwerkingsapparatuur. De verwerkingstemperaturen liggen rond de $160-180{ }^{\circ} \mathrm{C}$. Advies is PHA's, voor verwerking in de smelt, te drogen aangezien bij hogere temperaturen thermische degradatie kan optreden. Een nadeel van PHA's is de lage smeltsterkte tijdens verwerking en de zeer lage smeltviscositeit. De meest toegepaste verwerkingstechnieken voor PHA's zijn op dit moment spuitgieten, sheet extrusie en 
thermovormen. Er wordt veel onderzoek gedaan naar de verwerking van PHA's via andere verwerkingstechnieken.

\subsubsection{Eigenschappen}

Belangrijke commercieel beschikbare PHA's zijn polyhydroxybutyraat ( $\mathrm{P} 3 \mathrm{HB}$ en P3HB4HB), polyhydroxybutyraatvaleraat (PHBV) en polyhydroxybutyraathexanoaat $(\mathrm{PHBH})$. PHA's kunnen eigenschappen hebben die vergelijkbaar zijn met elastomeren (rubberachtig) of met hoog kristallijne polymeren met een smeltpunt van $175^{\circ} \mathrm{C}$. Enkele voorbeelden:

- $\quad \mathrm{PHB}$ is een hoog kristallijn thermoplastisch materiaal dat stijver is dan PP; het is erg bros en dat beperkt de toepasbaarheid van het materiaal

- $\quad$ PHBV is taaier en heeft een stijfheid die iets hoger is dan PP (1000-2000 MPa), en een breukrek van $10 \%$ tot $50 \%$

- $\quad$ P3HB4HB en PHBH hebben mechanische eigenschappen (o.a. rek bij breuk), die zeer vergelijkbaar zijn met PP en HDPE

Voordelen van PHA's ten opzichte van andere biopolymeren zijn hun uitstekende biologische afbreekbaarheid in combinatie met een hoge maximale gebruikstemperatuur en hydrofobiciteit.

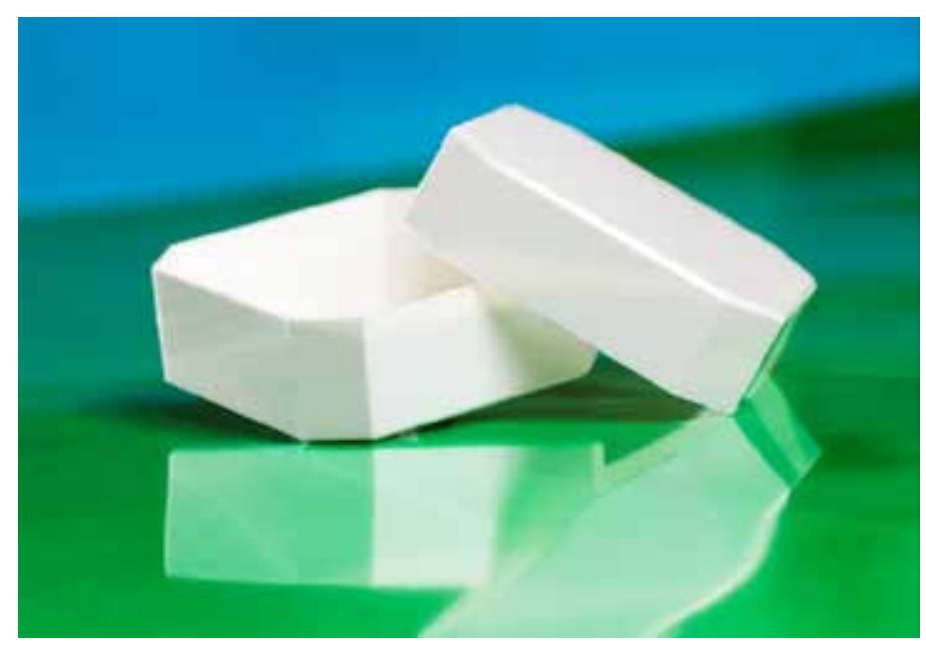

Doosje op basis van PHA (Kaneka)

PHA's zijn composteerbaar (ook geschikt voor thuiscompostering) en ook biologisch afbreekbaar in anaerobe vergistingsinstallaties, in de bodem en zelfs in zee. Daarbij is de afbraak in zee veel langzamer dan bijvoorbeeld in de grond. De waterdampbarrière 
van PHA's is vergelijkbaar met die van polyolefinen (PE, PP) wat voordelen biedt ten opzichte van andere biobased plastics. PHA's zijn niet transparant en dit kan een nadeel zijn in sommige verpakkingstoepassingen.

\subsubsection{Toepassingen}

Door de vrij hoge marktprijs van PHA's liggen toepassingen waar de prijs geen belemmering vormt voor de hand zoals medische en farmaceutische toepassingen (schroeven, chirurgische platen, stents). In het verleden werden in Japan shampooflessen en creditcards gemaakt van PHA's. Op dit moment worden PHA's steeds vaker commercieel toegepast in biobased polymeerblends; zo kunnen PHA's bijvoorbeeld worden ingezet als impact modifier om de slagvastheid (taaiheid) van PLA te verbeteren.

De huidige PHA-producenten richten zich op toepassingen zoals coatings voor papieren bekertjes, diverse disposables, onkruidwerende folies, vezels, bloempotten, verpakkingen van voedingsmiddelen, duurzame goederen en toepassingen in de persoonlijke verzorging.

\subsubsection{Verkrijgbaarheid en prijs}

$\mathrm{ICl}$ was in de jaren '80 een pionier op het gebied van de commerciële productie van PHA's. Vanwege de hoge productiekosten waren de toepassingen destijds beperkt. Tegenwoordig is er een hernieuwde belangstelling voor PHA's, voornamelijk om de specifieke eigenschappen die PHA's onderscheiden ten opzichte van andere commercieel beschikbare biobased polymeren.

Sinds de eerste marktintroductie door ICl zijn de productiekosten van PHA's aanzienlijk gedaald. Ook in de toekomst wordt een verdere prijsdaling verwacht. Op dit moment worden PHA's door diverse producenten uit Amerika, Brazilië, China en Japan aangeboden tegen marktprijzen van $€ 4$ tot $€ 5$ per $\mathrm{kg}$. Specifieke PHA's (blends) voor biomedische toepassingen hebben marktprijzen van $€ 10-15$ per $\mathrm{kg}$.

Hoewel op dit moment de productiecapaciteit beperkt is (ongeveer 70 kton per jaar), zijn er plannen voor de uitbreiding van de productie capaciteit. Het succes van deze plannen is sterk afhankelijk van de marktontwikkeling, schaalvoordelen en het gebruik van tweede generatie grondstoffen zoals lignocellulose of reststromen.

\subsubsection{Ontwikkelingen}

Toekomstige ontwikkelingen richten zich op kostenbesparingen door middel van geoptimaliseerde productieprocessen, goedkopere grondstoffen, grootschalige fabrieken en vereenvoudigde down stream processing (het isoleren van PHA's uit microorganismen). Er wordt met name veel onderzoek gedaan naar het produceren van PHA's in afvalwaterzuiveringsinstallaties. Van nature komen in deze installaties PHA 
producerende micro-organismen voor en de hoeveelheid van deze micro-organismen kan sterk worden vergroot tot hoeveelheden die een rendabele oogst van PHA mogelijk maken.

De verwachting is dat het scala aan commercieel beschikbare PHA-grades zal toenemen. Via productontwikkeling en blenden met andere biobased polymeren kunnen materialen en producten met een goede prijs/kwaliteit verhouding worden ontwikkeld.

\subsection{Natuurrubber}

Natuurrubbers zijn elastische materialen (elastomeren) die zich aanpassen onder druk of rek, en daarna kunnen terugkeren naar hun oorspronkelijke afmeting. Dit elastische gedrag wordt veroorzaakt door de lange polymeerketens die (licht) gecrosslinked zijn waardoor vervormingen omkeerbaar worden en doordat ze bij normale gebruikstemperatuur in de rubbertoestand zijn (boven de $T_{g}$ ).

Het gebruik van elastomeren was bekend bij de Indianen uit Zuid- en Midden-Amerika. Ze produceerden rubberproducten uit de latex van een aantal planten, waaronder Hevea brasiliensis. Rubber gemaakt van de latex van deze boom werd in Europa bekend in het midden van de $18^{\mathrm{e}}$ eeuw. De grote doorbraak van natuurrubber komt voort uit de ontdekking van vulkanisatie in 1838 door Charles Goodyear, die latex met zwavel verwarmde en ontdekte dat de rubbereigenschappen sterk werden verbeterd.

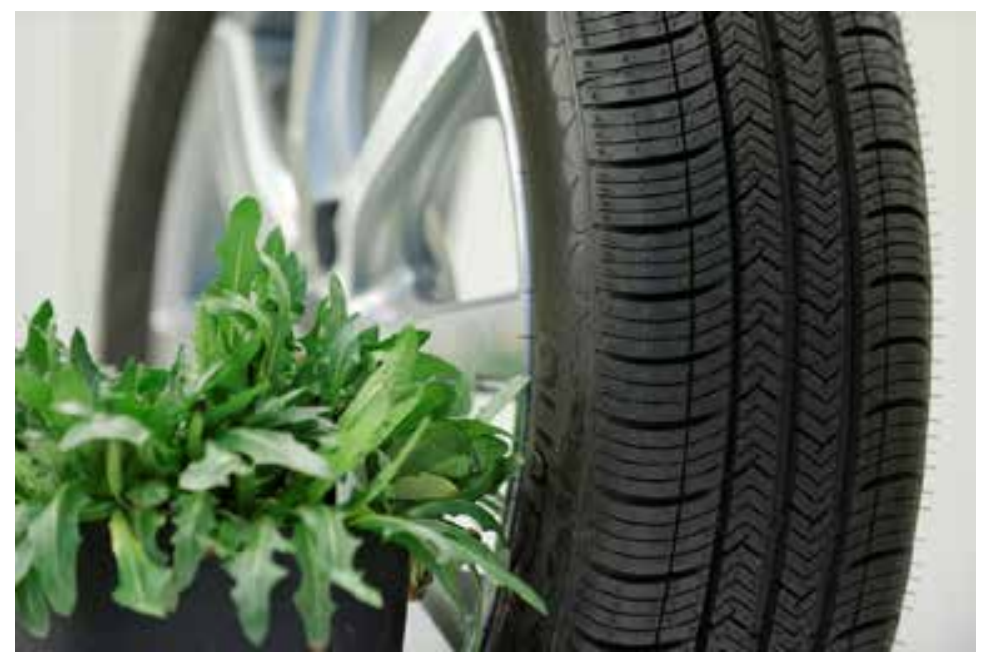

Loopvlak op basis van rubber uit Taraxacum koksaghyz (Apollo Vredestein)

Natuurrubber is een polymerisatieproduct van cis-1,4-isopreen. Hoewel polyisopreen ook synthetisch kan worden gemaakt via de polymerisatie van (petrochemisch) 
isopreen, heeft natuurrubber van de Hevea boom een groot marktaandeel behouden. Vanwege het zeer hoge molecuulgewicht en de hoge stereochemische zuiverheid heeft natuurrubber in bepaalde toepassingen de voorkeur, zoals voor chirurgische handschoenen en banden voor vliegtuigen. De wereldproductie van rubber is ongeveer 24 miljoen ton, waarvan natuurrubber een aandeel heeft van ongeveer $40-45 \%$. Natuurrubber wordt hoofdzakelijk geproduceerd in Zuidoost-Azië.

De afhankelijkheid van de latex van Hevea brasiliensis als enige bron van natuurlijk rubber heeft een aantal nadelen. De Hevea boom kent weinig genetische variatie waardoor de rubberplantages een groot risico lopen op ernstige plagen (zoals leaf blight). De boom groeit alleen in zeer specifieke klimaten; zo kan de Hevea niet worden gekweekt in gematigde klimaten. Daarnaast zijn sommige mensen allergisch voor de eiwitten aanwezig in natuurlijke latex.

Een zoektocht naar alternatieve rubber producerende planten heeft geleid tot de ontdekking van 2500 andere soorten die cis-1,4-polyisopreen produceren, waarvan sommige van goede kwaliteit. Twee planten die het meest veelbelovend lijken als alternatieve bron van natuurrubber zijn Parthenium argentatum (guayule), een struik afkomstig uit Mexico, en Taraxacum koksaghyz (Russische paardenbloem), die tijdens de Tweede Wereldoorlog in Rusland is gebruikt om banden te produceren. Naast deze zoektocht naar alternatieve bronnen voor natuurrubber wordt gewerkt aan biotechnologische routes voor de productie van isoprenen. Deze biobased isoprenen kunnen gepolymeriseerd worden tot polyisoprenen. 


\section{Verwerking van biobased plastics tot producten}

\subsection{Introductie}

In de vorige hoofdstukken zijn de verschillende soorten biobased plastics besproken, inclusief eigenschappen, verwerking, toepassing en beschikbaarheid. Dit hoofdstuk voegt extra informatie toe over de conversie van biobased plastics tot producten. Het bevat informatie over mogelijkheden die additieven, blenden en het gebruik van vulstoffen bieden om biobased plastic producten te maken.

\subsection{Additieven}

\subsubsection{Inleiding}

Naast de ontwikkeling van nieuwe polymeren is het succes van plastics voor een belangrijk deel te danken aan toevoegingen die de eigenschappen van eindproducten verbeteren (zoals UV-stabiliteit, taaiheid), de verwerkbaarheid van polymeren verbeteren (zoals vloeiverbeteraars, lossingsmiddelen) of eigenschappen toevoegen (zoals kleur). Dit worden ook wel additieven genoemd. Voor de toepassingen van additieven in plastics moet rekening worden gehouden met de aard van het polymeer, de specifieke eigenschappen die verbeterd moeten worden en de gewenste functionaliteit van het product.

\subsubsection{Additieven voor biobased plastics}

Additieven die ontwikkeld zijn voor PE zijn ook geschikt voor gebruik in bioPE en additieven voor traditionele polyamides kunnen ook worden toegepast in biobased polyamides. Echter, voor nieuwe polymeren zoals PLA en PHA's zijn specifieke additieven ontwikkeld die zich richten op de karakteristieke eigenschappen van deze plastics:

- Chain-extenders (ketenverlengers) of branching agents (additieven die vertakkingen aanbrengen) die worden toegepast om de smeltsterkte van PLA en PHA's te verhogen

- Nucleating agents (kiemvormers) die de kristallisatie snelheid van PLA en PHA's verhogen

- Additieven die hydrolyse tijdens verwerkingsprocessen tegengaan; veel bioplastics zijn polyesters en daarmee gevoelig voor hydrolyse

Additieven kunnen naast hun beoogde functie andere eigenschappen nadelig beïnvloeden. Impact modifiers kunnen bijvoorbeeld de transparantie van PLA verlagen. Diverse producenten hebben impact modifiers ontwikkeld die de taaiheid van PLA verhogen zonder de transparantie te beïnvloeden. Meer specifiek voor biobased plastics 
kan de toepassing van additieven zowel de biologische afbreekbaarheid als de biobased content beïnvloeden.

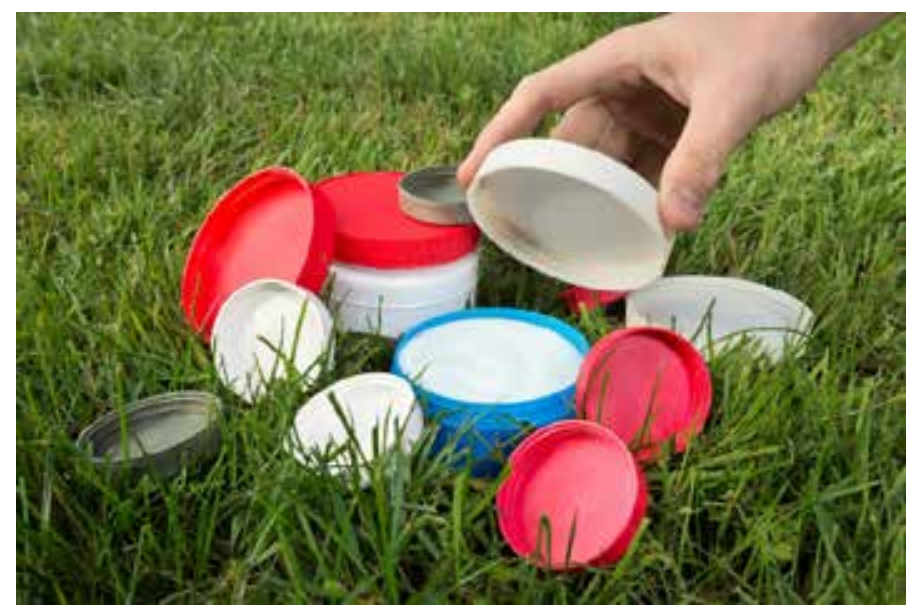

Ingekleurde bioplastic producten

\subsubsection{Additieven voor biologisch afbreekbare producten}

De EN13432 norm voor composteerbare materialen stelt dat alle componenten die worden toegevoegd aan een product in hoeveelheden groter dan $1 \%$ gewichtsprocent, biologisch afbreekbaar moeten zijn. Additieven zoals impact modifiers zijn pas functioneel bij toevoegingen van 5 tot $10 \%$. Om te blijven voldoen aan de EN13432 norm moeten dus biologisch afbreekbare impact modifiers toegepast worden. Omdat veel polymeerverwerkers alleen in staat zijn additieven in de vorm van voorgemengde concentraten of masterbatches toe te voegen, worden specifieke masterbatches op basis van biopolymeren ontwikkeld en gebruikt.

\subsubsection{Biobased additieven}

Ook voor biobased plastics waar biologische afbreekbaarheid geen noodzakelijke eigenschap is, heeft de markt behoefte aan nieuwe biobased additieven. De meeste additieven voor biobased polymeren worden geproduceerd uit fossiele grondstoffen. Wanneer deze worden toegevoegd aan het product neemt de biobased content af. Dit geldt in belangrijke mate voor impact modifiers maar nog meer voor weekmakers. Soms worden deze toegevoegd in hoeveelheden van zelfs meer dan $25 \%$.

Voorbeelden van commercieel verkrijgbare biobased weekmakers zijn triacetine (op basis van glycerol), citraat weekmakers (op basis van citroenzuur), weekmakers op basis van ricinusolie, lineaire di-esters zoals sebacaat esters (gebaseerd op natuurlijke zuren) en isosorbide esters. Deze biobased weekmakers worden niet alleen gebruikt in 
biobased plastics maar ook in traditionele polymeren (zoals PVC) vanwege hun specifieke eigenschappen. Daarbij zijn biobased weekmakers vaak minder schadelijk voor mens en milieu dan de veelal toegepaste ftalaat weekmakers.

\subsection{Blends}

Naarmate er meer biobased polymeren beschikbaar komen is mengen (ook wel blenden of compounderen genoemd) een effectieve manier om eigenschappen van biobased plastics verder te verbeteren en aan te passen. Op het gebied van blends kunnen twee verschillende ontwikkelingen onderscheiden worden. Enerzijds wordt gewerkt aan de ontwikkeling van biologisch afbreekbare materialen en producten en anderzijds aan materialen en producten die een zo hoog mogelijke biobased content hebben. Bij het blenden kan namelijk zowel de biologische afbreekbaarheid als het percentage biobased grondstoffen worden beïnvloed. Bij beide type producten wordt gewerkt met zogenaamde hybrides: een combinatie van een fossiel gebaseerd polymeer met een biobased plastic. Ook wordt het ene polymeer soms toegevoegd aan het andere of andersom. Een aantal voorbeelden:

- Blends van zetmeel met PBAT (polybutyleenadipaat tereftalaat). PBAT is biologisch afbreekbaar en composteerbaar volgens Europese normen maar op dit moment gebaseerd op fossiele grondstoffen

- $\quad$ PBAT wordt toegevoegd aan PLA om de taaiheid te verbeteren en de productie van flexibele folies met een goede scheurweerstand mogelijk te maken

- Aan zetmeel (TPS) worden andere biobased plastics, zoals PLA toegevoegd, om de sterkte en modulus te verhogen en de waterbestendigheid te verbeteren

- Blends van PLA en zetmeel (of PBAT) zijn wel bodem degradeerbaar en kunnen worden toegepast als afdekfolies die de groei van onkruid tegengaan. PLA is weliswaar biologisch afbreekbaar en composteerbaar maar niet afbreekbaar in de bodem

- $\quad$ Aan ABS (acrylonitril butadieen styreen) en PC (polycarbonaat) wordt PLA toegevoegd om de biobased content van computer behuizingen te verhogen

- Blends van PLA en PMMA zijn mengbaar en leveren een Plexiglas materiaal met uitstekende eigenschappen en een hogere biobased content.

Deze voorbeelden laten zien dat er vele combinaties mogelijk zijn als je enkel kijkt naar biologische afbreekbaarheid en/of biobased content. Er zijn dan ook veel marktpartijen die blends of masterbatches aanbieden. Niet altijd worden echter de juiste claims gemaakt. Zo wordt bij zetmeel gemengd met PE soms ook geclaimd dat het biologisch afbreekbaar is en van zetmeel met PBAT dat het volledig biobased is. Keuzes worden echter ook gemaakt op basis van de gewenste eigenschappen en prijs. Voor 
transparante folies worden andere materiaalcombinaties gebruikt dan voor spuitgietproducten waar transparantie niet vereist is. PHA, PLA, en TPS zijn biobased; PBAT en PBS niet (of nog niet). In de bioplastic blends zijn TPS en PLA de goedkoopste componenten. PLA wordt daarnaast toegepast vanwege haar stijfheid en transparantie. PBAT en PBS worden toegevoegd om de taaiheid te verbeteren en om de maximale gebruikstemperatuur te verhogen (HDT). Zetmeel en PHA kunnen ook worden toegevoegd ter verbetering van de biologische afbreekbaarheid.

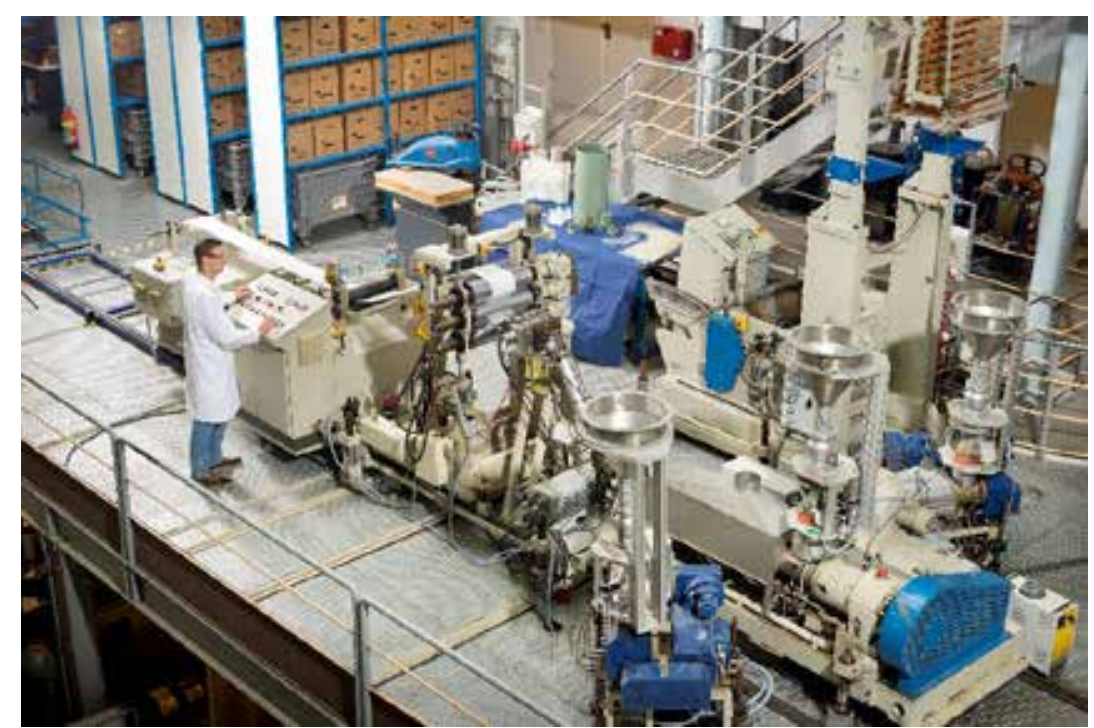

Productie van meerlaags bioplastic sheets

\subsection{Vulstoffen}

Omdat de meeste biobased polymeren op dit moment nog duurder zijn dan fossiele polymeren worden vaak vulstoffen toegevoegd om materiaalkosten te reduceren. Daarnaast kunnen vulstoffen worden toegevoegd om de stijfheid te verhogen en soms ook de sterkte of zelfs de kristallisatiesnelheid. Minerale vulstoffen die veel worden toegepast zijn talk en krijt. Ook worden organische vulstoffen zoals houtmeel, natuurlijke vezels of zelfs tarwebloem toegepast. Over het algemeen maken vulstoffen plastic materialen bros waardoor weer (additionele) toevoeging van impact modifiers nodig is. Volgens de EN13432 norm is de toevoeging van vulstoffen toegestaan tot $50 \%$. Organische vulstoffen kunnen de snelheid van biologische afbraak verhogen. 


\subsection{Productontwikkeling}

Wanneer producten worden ontwikkeld op basis van biobased polymeren is het belangrijk onderscheid te maken tussen de drop-in biobased plastics en "nieuwe" biobased plastics. Drop-in biobased plastics zoals bioPE en bioPE zijn een 1 op 1 vervanging van respectievelijk PE en PET. Productontwerp, processing, gebruik tot en met de afvalfase zijn identiek. Wanneer echter nieuwe biobased plastics worden ingezet zoals PLA en PBS is redesign gewenst, kan gebruik gemaakt worden van conventionele productiemachines, maar zullen procescondities moeten worden aangepast, etc. etc. Op basis van de eigenschappen van de specifieke biobased polymeren kan een inschatting gemaakt worden welke traditionele kunststoffen vervangen kunnen worden. Zo is PLA een prima vervanging voor PS (polystyreen) en soms PET (gethermovormde trays en bekers) en zijn zetmeelfolies afhankelijk van de specifieke applicatie een goede vervanger van (LD)PE. Redesign geeft voordelen ten aanzien van functionaliteit. Zo kunnen PLA-yoghurtbekers dunner zijn dan PS-yoghurtbekers vanwege de hogere stijfheid van PLA. Wanneer PE mulchfilms worden vervangen door zetmeel gebaseerde mulchfilms die afbreekbaar zijn in de grond, kunnen ook veel dunnere folies toegepast worden. 


\section{Duurzaamheid}

\subsection{Introductie}

De twee belangrijkste aspecten van de relatie tussen fossiele plastics, biobased plastics en duurzaamheid zijn enerzijds de postitive invloed op klimaatverandering via de vervanging van fossiele grondstoffen door biomassa en anderzijds hoe we omgaan met afval. Met name de discussie over de plastic soep heeft de gemoederen hierin de laatste jaren flink beziggehouden.

De Ellen MacArthur foundation heeft een visie rondom de nieuwe plastic economie opgesteld, waarin beter recyclen van plastics en het produceren van nieuwe plastics uit biomassa de kernthema's zijn.

\subsection{Klimaat en landgebruik}

Klimaatverandering is de meest genoemde reden om biobased plastics in te zetten. Afgelopen jaren zijn verscheidene "cradle to factory gate" levenscylus analyses (LCA) uitgevoerd naar de duurzaamheid van de productie van biobased plastics. Bij deze LCA's wordt gekeken naar de milieubelasting van de bioplasticproductie, startend vanaf de productie van het gewas tot en met de productie van het bioplastic in de fabriek. Recente publicaties laten over het algemeen een positief beeld zien als biobased plastics worden vergeleken met plastics uit fossiele grondstoffen.

Een studie uit $2011^{4}$ waarbij de productie van bioplastics en biobrandstoffen uit fermenteerbare suikers is vergeleken laat enkele interessante conclusies zien. Centrale onderzoeksvraag was, gegeven een beperkte hoeveelheid landbouwgrond, welk gewas het beste kan worden ingezet om de fermenteerbare suikers te produceren en welk product er het beste uit kan worden gemaakt.

Uit de studie blijkt dat de productie van zowel PLA als bioPE minder niet-hernieuwbare energie kost dan de productie van de fossiele tegenhangers PET en fossiel PE en dat deze in beide gevallen ook minder broeikasgasuitstoot met zich meebrengt. Verder blijkt dat het inzetten van de biomassa voor bioplastics leidt tot een grotere vermindering van de broeikasgasuitstoot dan het gebruik voor de biobrandstof ethanol.

Een belangrijk verschil is dat met name op landgebruik PLA beter scoort dan bioPE. Dit verschil is terug te voeren op het verschil tussen biomassa en aardolie. Aardolie bestaat alleen uit koolstof en waterstofatomen, terwijl biomassa ook veel zuurstofatomen en in sommige gevallen stikstofatomen bevat. Een bioplastic zoals PLA, die nog veel van de zuurstofatomen bevat die de plant heeft ingebouwd, heeft dus minder grondstof nodig per ton geproduceerde plastic en komt daardoor beter uit de vergelijking dan een

${ }^{4}$ Bos, Conijn, Corré, Meesters, Patel, Duurzaamheid van biobased producten, energiegebruik en broeikasgasemissie van producten met suiker als grondstof. Groene grondstoffenreeks 11. (2011) 
bioplastic als bioPE, waarbij tijdens de productie veel van de oorspronkelijk ingebouwde atomen worden afgesplitst als $\mathrm{CO}_{2}$ en water. $\mathrm{Bij}$ de productie van plastics uit aardolie zijn juist de plastics in het voordeel die alleen uit koolstof en waterstofatomen bestaan, zoals $\mathrm{PE}$, vooral ook omdat het chemisch inbouwen van zuurstof- of stikstofatomen erg veel energie kost.

Naast broeikasgasemissies en niet-hernieuwbaar energiegebruik zijn nog andere milieuaspecten van belang, zoals het gebruik van water, uitstoot van verzurende stoffen en fijnstof, eutrofiëring, etcetera. Deze milieuaspecten zijn voor een belangrijk deel gerelateerd aan de landbouw, ten opzichte van fossiel gebaseerde plastics kunnen bioplastics op deze impactcategoriën tot een hogere impact leiden. Verduurzaming van de landbouw kan in dit geval ook een positief effect hebben op de duurzaamheid van bioplastics.

\subsection{Beschikbaarheid van biomassa}

Een veel gestelde vraag bij het gebruik van biomassa voor bioplastics is of er wel genoeg biomassa beschikbaar is om de bioplastics te maken en of dit niet ten koste gaat van de wereldvoedselvoorziening.

\section{Land use estimation for bioplastics 2017 and 2022}

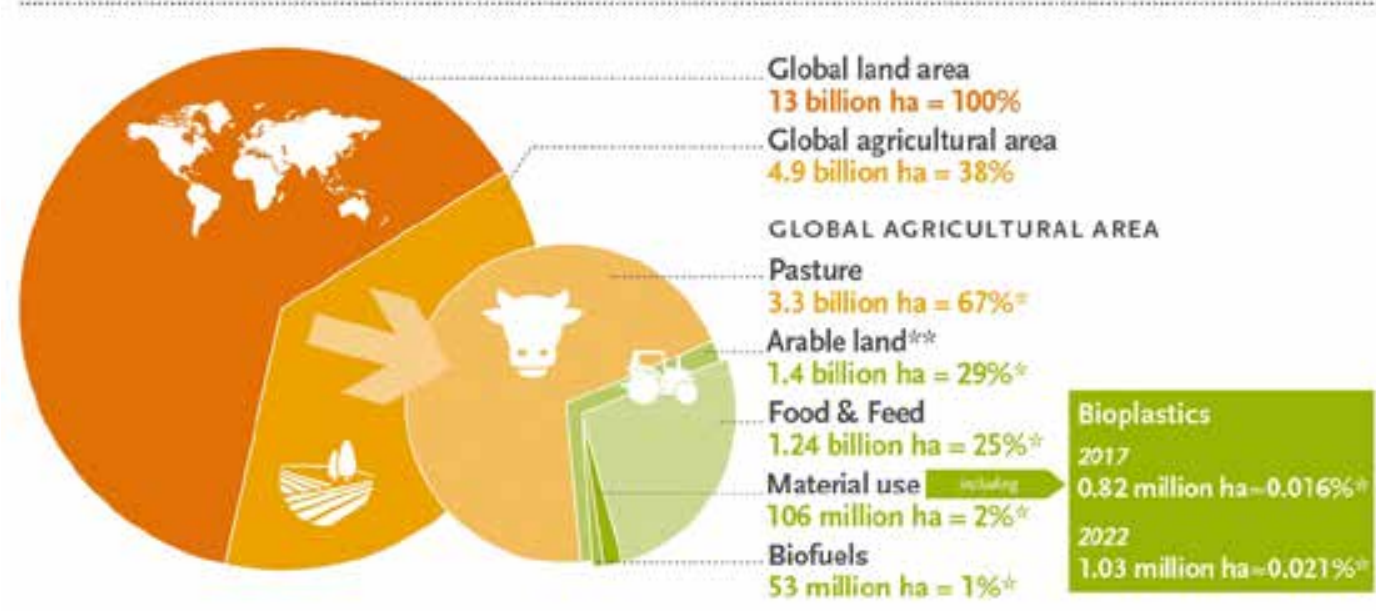

Source: European Bioplastics (2017), FAO Stots (2014), nowa-institute (2017), and Institute for Bioplastics and Biocomposites (2016). More information: wiw.european-bloplastics.org

Landbouwgrond gebruikt voor bioplastics productie ten opzichte van totale landbouwgrond beschikbaar. (European Bioplastics) ${ }^{5}$

${ }^{5}$ https://www. european-bioplastics.org/ 
Belangrijk is hierbij de verhouding tussen de hoeveelheid biomassa, of landbouwgrond, die wordt ingezet ten opzichte van de andere toepassingen van biomassa, voedsel, veevoer en biobrandstoffen. European Bioplastics geeft hier een inzichtelijke infographic over (zie figuur op de vorige pagina). De gebruikte hoeveelheid landbouwgrond voor bioplastics is vooralsnog minimaal ten opzichte van de andere toepassingen, en ook wanneer we alle fossiele plastics zouden willen vervangen door bioplastics zal dit niet meer dan enkele procenten van het landbouwareaal kosten. Interessant hierbij is een recente studie van Kline et al. ${ }^{6}$ warin wordt onderbouwd dat juist het integreren van voedsel en biobrandstoffen productie kan leiden tot een betere grondstoffen-basis. De outlet naar meerdere markten kan hierbij juist leiden tot stabilisering van prijzen voor biomassa grondstoffen, en daarmee tot een intensivering van de productie en een grotere beschikbaarheid van biomassa grondstoffen. Dit mechanisme gaat vanzelfsprekend ook op voor de productie van biomassa voor bioplastics.

\subsection{Afvalbeheer en circulariteit}

Naast de herkomst van de grondstoffen voor biobased plastics is de wijze van afvalbeheer ook van invloed op de milieubelasting, al blijkt de impact bij levenscyclus analyses vaak minder groot. De materiaaleigenschappen bepalen de wijze van afvalbeheer, en daarmee in grote mate de milieu impact in de afvalfase. In paragraaf 1.4 is al aan bod gekomen dat sommige biobased plastics zoals PLA, PHA's, TPS en geregenereerd cellulose ook biologisch afbreekbaar kunnen zijn en dat zelfs petrochemische plastics als PBS, PCL en PBAT biologisch afbreekbaar kunnen zijn. In deze paragraaf worden daarom biologisch afbreekbare plastics en biobased plastics apart van elkaar besproken.

Plastic zwerfafval en plastic soep?

Het is zeer lastig om materialen zo te ontwerpen dat ze voldoen aan alle eisen die worden gesteld tijdens het functionele gebruik en dat ze tegelijkertijd in elk willekeurig milieu binnen afzienbare tijd biologisch afbreken op het moment dat ze worden afgedankt. Biologisch afbreekbare materialen lijken daarom geen technische oplossing voor het zwerfafvalprobleem en daarmee ook niet voor het probleem van de plastics in de wereldzeeën. Dit nog los van de vraag of de maatschappij materialen niet liever hergebruikt én de vraag of het weggooien van producten überhaupt wel sociaal gewenst gedrag is. Een vorm van collectieve discipline lijkt voorlopig de enige oplossing. Ook het creëren van waarde voor het afval kan een stimulans zijn om plastic afval te verzamelen. Complicatie is dat slechts weinig landen een goed functionerend gesloten afvalsysteem hebben.

${ }^{6}$ Keith L. Kline et al. Reconciling food security and bioenergy: priorities for action, GCB Bioenergy (2017) 9, 557-576, doi: 10.1111/gcbb.12366 
Biologisch afbreekbare plastics

Veel biologisch afbreekbare plastics kunnen afbreken in een gecontroleerde omgeving zoals in een composterings- of vergistingsinstallatie en vaak ook in een goed werkende composthoop in de achtertuin. Sommige biologisch afbreekbare plastics kunnen ook afbreken bij een tuinder in de grond of zelfs in zout of zoet water. Bij gecontroleerd composteren wordt het biobased plastic omgezet in $\mathrm{CO}_{2}$ en water dat als grondstof kan dienen voor het maken van nieuw plantaardig materiaal. Bij vergisten onstaat biogas,

Indeling van plastics op bioafbreekbaarheid en oorsprong

\begin{tabular}{|c|c|c|c|}
\hline & Petrochemisch & Gedeeltelijk biobased & Biobased \\
\hline $\begin{array}{l}\text { Niet biologisch } \\
\text { afbreekbaar }\end{array}$ & $\begin{array}{l}\text { PE } \\
\text { PP } \\
\text { PS } \\
\text { PVC } \\
\text { PET } \\
\text { PUR }\end{array}$ & $\begin{array}{l}\text { PET (biobased etheen) } \\
\text { PTT (biobased 1,3-PDO) } \\
\text { PUR (biobased polyolen)) } \\
\text { Nylon } 6,10\end{array}$ & $\begin{array}{l}\text { PE } \\
\text { Nylon } 11 \\
\text { Nylon } 10,10 \\
\text { Natuur rubber }\end{array}$ \\
\hline $\begin{array}{l}\text { Biologisch } \\
\text { afbreekbaar }\end{array}$ & $\begin{array}{l}\text { PCL } \\
\text { PBAT }\end{array}$ & $\begin{array}{l}\text { Zetmeel blends } \\
\text { PBS }\end{array}$ & $\begin{array}{l}\text { PLA } \\
\text { PHA's } \\
\text { PHA's } \\
\text { TPS } \\
\text { Geregenereerd cellulose }\end{array}$ \\
\hline
\end{tabular}

dat naast $\mathrm{CO}_{2}$ ook methaan $\left(\mathrm{CH}_{4}\right)$ bevat. Bij ongecontroleerde biologische afbraak buiten een vergistingsinstallatie heeft een verbinding zoals methaan overigens een negatief effect omdat dit een broeikasgas is dat 25 keer meer actief is dan $\mathrm{CO}_{2}$.

Milieutechnisch lijkt compostering niet de meest ideale vorm van afvalbeheer voor biologisch afbreekbare plastics. In het composteringsproces gaat de energie-inhoud van de polymeren immers grotendeels verloren. Productie van energie, rechtstreeks door verbranding of indirect via de productie van biogas als intermediair, lijkt over het algemeen een betere oplossing. Toch kan biologische afbraak van materialen in specifieke gevallen ook milieutechnisch de voorkeur hebben, zoals in de landbouw waar afbreekbare materialen (bodembedekking, clips, potten) na gebruik kunnen vergaan.

Biobased plastics

Voor biobased plastics die niet biologisch afbreekbaar zijn is de beste afvalroute niet anders dan voor petrochemische polymeren. Chemische-, materiaal-, of productrecycling is de beste optie. Hergebruik is mogelijk wanneer het gerecyclede materiaal chemisch gezien voldoende homogeen is. Voor industrieel afval lijkt dit mogelijk. Voor consumentenafval is dit veel moeilijker, omdat het scheiden van de verschillende plastic fracties technisch niet eenvoudig is. Ook is er meestal sprake van 
zogenaamde downgrading; er wordt plastic geproduceerd van mindere kwaliteit dan het origineel. Dit geldt voor zowel biobased als traditionele plastics. Wanneer we naar het Ellen Mac Arthur model kijken voor de "nieuwe plastic economie" is het wel cruciaal om betere recycling technologieën te ontwikkelen. Zeker omdat $40 \%$ van alle kunststoffen worden toegepast in verpakkingen en deze uiteindelijk vaak in het consumentenafval terecht komen. Hoe beter we in staat zijn te recyclen hoe minder biomassa er nodig is voor nieuwe plastics.

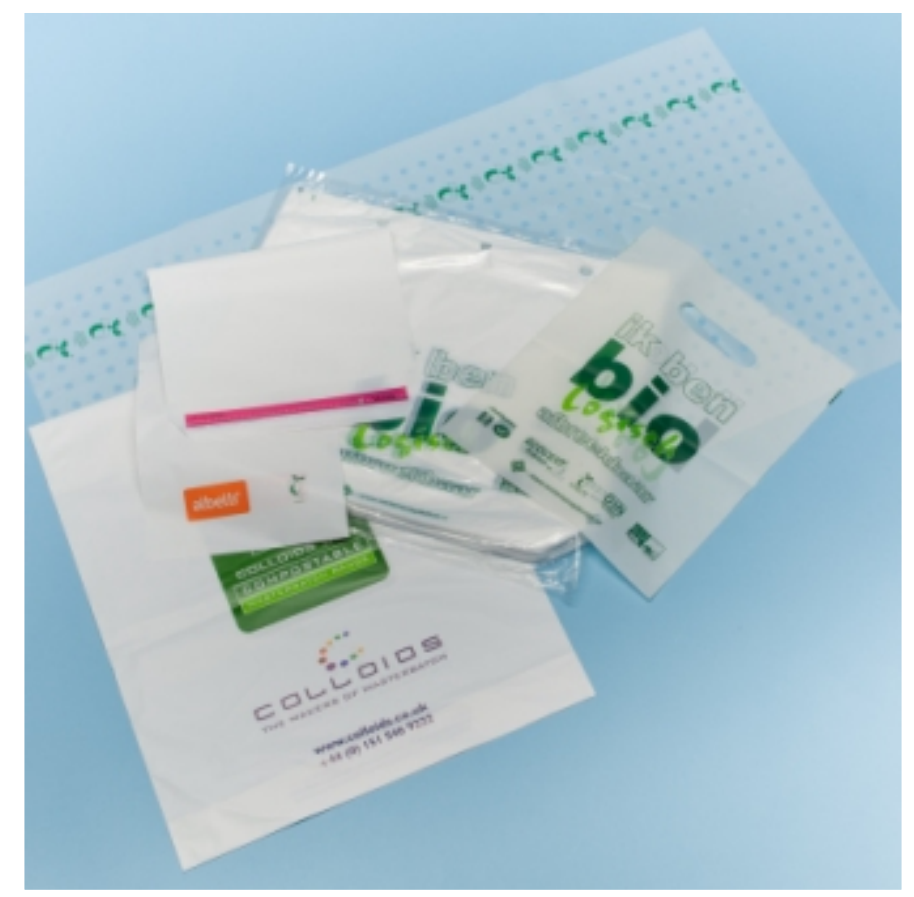

Composteerbare verpakkingen (Bron: Biobased Oerlemans Plastics)

\section{Circulariteit}

Op dit moment is onze "plastic economie" lineair. Wereldwijd wordt slechts $2 \%$ van de geproduceerde plastics circulair gebruikt. Een goed voorbeeld zijn frisdrankflessen op basis van PET. Daarnaast wordt zo'n $8 \%$ hergebruikt in laagwaardiger toepassingen. Deze lage percentages kunnen grotendeels verklaard worden door het feit dat slechts ca. $14 \%$ van de afgedankte kunststoffen worden ingezameld. Een schrikbarende hoeveelheid van $32 \%$ komt in het milieu terecht en zo'n $40 \%$ wordt gestort. In Nederland doen we het veel beter, omdat we sterk hebben ingezet op inzameling en circulair gebruik van verpakkingen (circa $40 \%$ van alle geproduceerde plastics worden in verpakkingen toegepast). Op dit moment wordt zo'n 38\% van het huishoudelijk 
kunststofverpakkingsafval apart ingezameld en wordt bovendien ongeveer $20 \%$ van het restafval nagescheiden. Daardoor wordt naar schatting $6 \%$ van de verpakkingen (huishoudelijk en bedrijfsafval) circulair hergebruikt. Ongeveer $20 \%$ van de huishoudelijke kunststofverpakkingen worden in minder veeleisende toepassingen hergebruikt. In Nederland wordt geen kunststofverpakkingsafval gestort.

$\mathrm{Er}$ is een grote transitie nodig om te komen tot een circulaire economie en het is de vraag of dit met onze huidige petrochemische kunststoffen lukt. Biobased polymeren en met name polyesters kunnen een belangrijke rol spelen in de transitie naar een circulaire plastic economie omdat ze eenvoudiger en via meerdere routes gerecycled kunnen worden. Een niet biobased voorbeeld van een goed recyclebare polyester is PET. Vergelijkbare recyclingtechnologieën zijn toepasbaar op bijvoorbeeld PEF en PLA.

\section{Conclusie}

Net zoals bij de reguliere plastics is voor biobased plastics een vorm van recycling (mechanisch of chemisch) de beste optie. Voor specifieke toepassingen, waarin het niet voorkomen kan worden dat kunststoffen in het milieu terecht komen, kunnen biologisch afbreekbare polymeren een oplossing bieden. Wanneer kunststofafval sterk vervuild is met organisch materiaal (levensmiddelen), is vergisting met biogasterugwinning een goede optie en kunnen biologisch afbreekbare kunststoffen ook voordeel bieden.

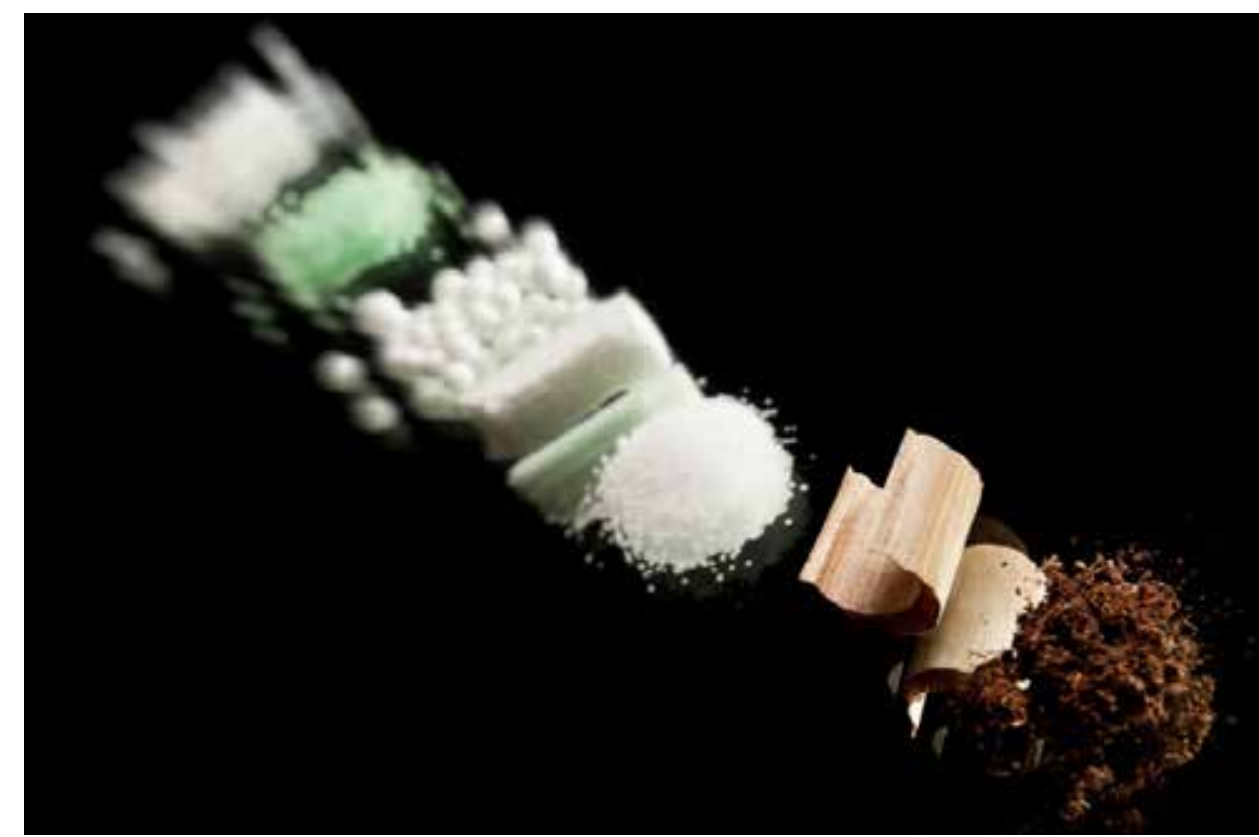

Levenscyclus van PLA 


\section{Marktomvang en vooruitzichten}

\subsection{Introductie}

Het gebruik van biobased grondstoffen voor materialen is niet nieuw. Wereldwijd wordt hout nog steeds veel gebruikt als bouw- en constructiemateriaal. Ongeveer $40 \%$ van alle textiel is van natuurlijke oorsprong, vooral katoen ( 30 miljoen ton) en door de mens gemaakte cellulose vezel (3,5 miljoen ton). Wereldwijd is de productie van papier en karton (ongeveer 400 miljoen ton in 2010) groter dan die van kunststof (ongeveer 250 miljoen ton). Andere markten voor biobased materialen zijn natuurrubber ( 9 miljoen ton) en alkydverf ( 1 miljoen ton).

\subsection{Marktaanbod}

Onderstaand figuur toont de stadia van ontwikkeling voor de verschillende in dit boek besproken biobased plastics. Opmerkelijk is dat elke ontwikkelingsfase wordt vertegenwoordigd door een aantal belangrijke producten. Bovendien zijn zowel volledig als gedeeltelijk biobased materialen aanwezig in elke technologische fase van ontwikkeling. Het is uiteraard niet verrassend dat meer materialen in een R\&D en pilotschaal fase zijn dan in een grootschalige commerciële productiefase.

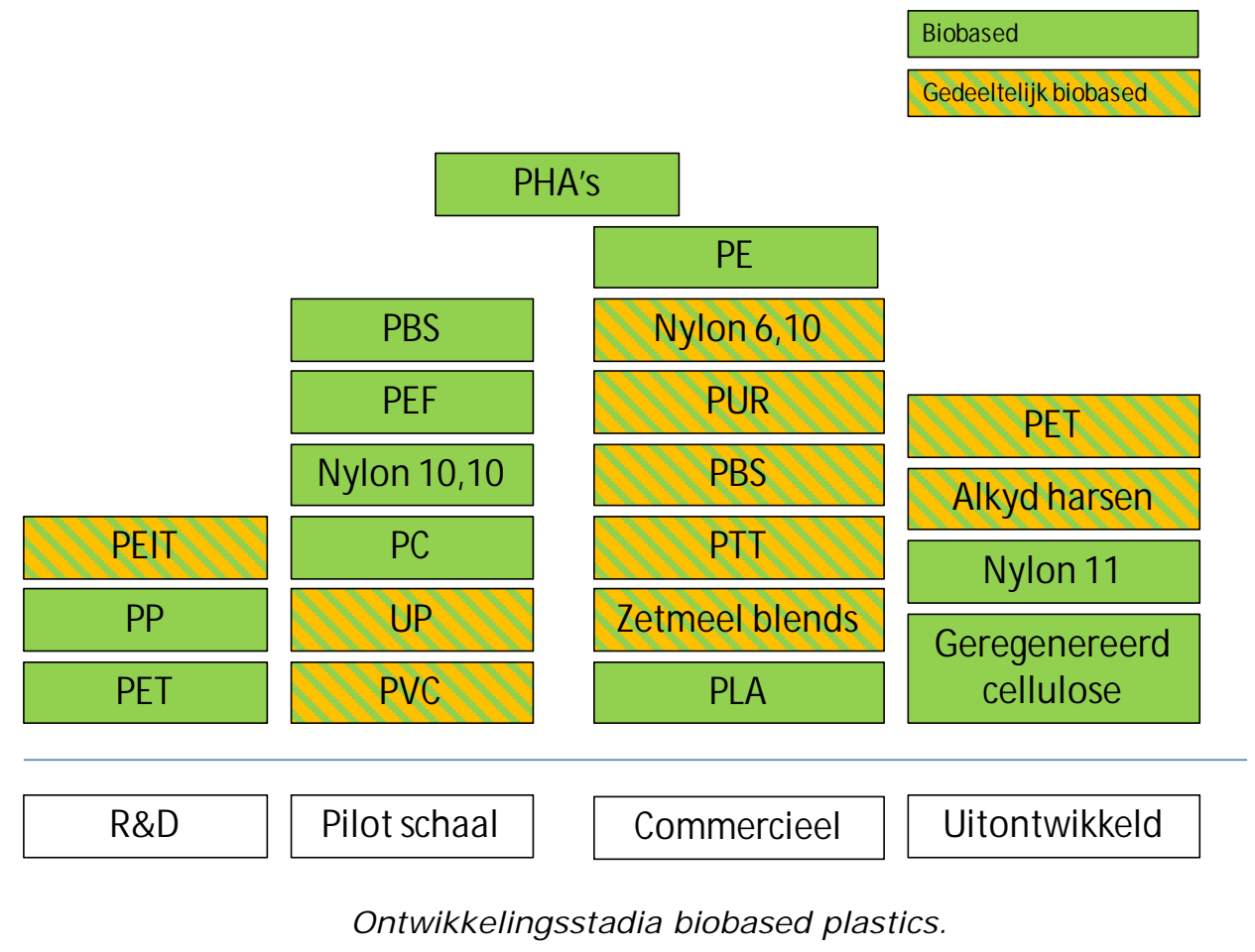




\subsection{Marktvraag}

In de huidige markt is te zien dat eindgebruikers, waaronder ook opvallend veel A-merken, steeds meer bereid zijn een hogere prijs te betalen voor milieuvriendelijke producten waaronder biobased materialen. Grote voedselproducenten zoals Danone, Nestlé, Unilever committeren zich aan het model van Ellen MacArthur en hebben aangekondigd dat in 2025 al hun verpakkingen recyclebaar of biobased zijn. Heinz en Coca-Cola hebben zich gecommitteerd aan het gebruik van biobased verpakkingsmateriaal via het ondersteunen van onderzoek voor de ontwikkeling van bioPET en PEF. Op deze wijze maken zij hun belofte om duurzamer te werken concreet. De keuze om synthetische plastics te vervangen door biobased plastics wordt ingegeven doordat burgers plastic verpakkingen vaak associëren met afvalproblemen. De wereld is momenteel bezaaid met plastic tasjes, en er bevinden zich drijvende eilanden van plastic afval in de oceanen. In het afgelopen decennium zijn daar andere maatschappelijke thema's bijgekomen, met name het broeikaseffect. Biobased plastics worden voor dit soort maatschappelijke thema's - soms onterecht overigens - gezien als een stap voorwaarts ten opzichte van synthetische plastics. Grote namen uit andere sectoren zoals de auto-industrie (Toyota, Ford) en de consumentenelektronica (Fujitsu, Sony) volgen om dezelfde reden.

\begin{tabular}{|l|l|}
\begin{tabular}{|l|l|}
\hline Mlastic & Marktprijs (€/ kg) \\
\hline PE & $1.25-1.45$ \\
\hline PS & $1.25-1.43$ \\
\hline ABS & $1.90-2.45$ \\
\hline PP & $1.00-1.200$ \\
\hline PC & $3.10-3.70$ \\
\hline TPS blends & 2.50 en hoger \\
\hline PLA & 1.80 en hoger \\
\hline PHA & $4.00-5.00$ \\
\hline PBS & $3.50-4.50$ \\
\hline PBAT & $3.30-3.70$ \\
\hline
\end{tabular}
\end{tabular}

Het prijsniveau van biobased plastics blijkt een grote doorslaggevende factor. De mate waarin de kostprijs fluctueert is belangrijk en de grondstoffen zijn prijsgevoelig. Dit geeft een stimulans aan de ontwikkeling van biobased plastics. In de afgelopen vijftien jaar fluctueerden de olieprijzen hevig. De prijzen van veel biobased grondstoffen zoals suikers zijn traditioneel aanzienlijk stabieler en vertonen relatief geen tot weinig stijging. De afgelopen vijftien jaar is dit in vergelijking met de olieprijs nog steeds het geval, al laten de wereldmarktprijsontwikkelingen zien dat agrogrondstoffen niet ontkomen aan 
een algehele prijsstijging. Met het oog op beschikbaarheid in relatie tot internationale conflicten lijkt de prijs van aardolie echter aan meer fluctuaties onderhevig vergeleken met biobased grondstoffen. De toekomst zal echter moeten uitwijzen of dit zo zal blijven.

Uit de prijsontwikkeling van plastics blijkt dat het prijsverschil tussen traditionele (goedkope) petrochemische plastics en de (relatief dure) biobased alternatieven nog aanwezig is. Eén van de redenen is dat de technologie om biobased plastics te maken minder ver is uitontwikkeld.

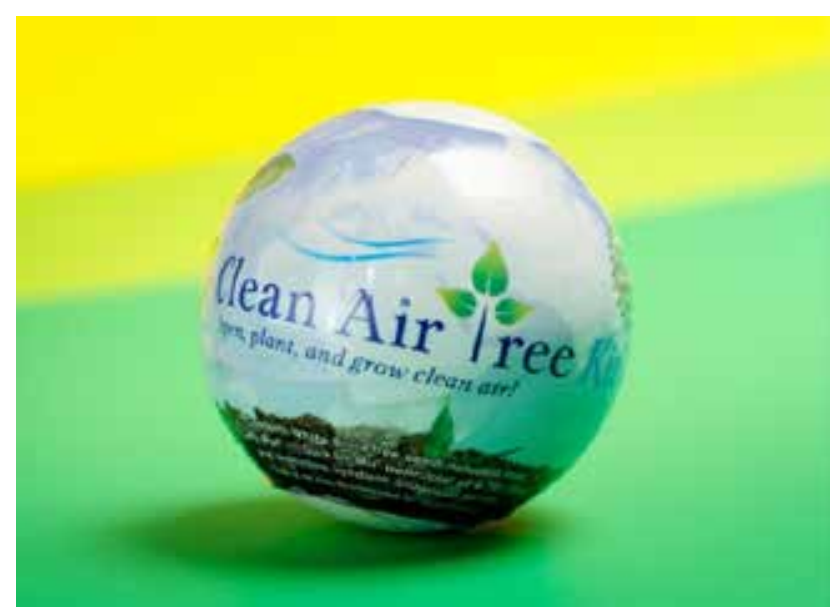

Verpakking samengesteld uit diverse biologisch afbreekbare kunststoffen

Kostenreductie wordt verwacht door kostenbesparingen in het proces, en door technologieën die het mogelijk moet maken om op een efficiënte manier (goedkopere) houtachtige biomassa in te zetten als grondstof. Biobased plastics worden momenteel op relatief kleine schaal geproduceerd; zodra deze materialen in grote aantallen geproduceerd worden zal het kostenplaatje er anders uit komen te zien. De kosten zullen gaan dalen als gevolg van de schaalvoordelen en door oplossing van voorkomende 'kinderziektes'. De wetenschappelijke basis voor de productie van biobased plastics breidt zich snel uit. In het bijzonder chemische katalyse, scheidingstechnologie en industriële biotechnologie zullen snelle ontwikkelingen doormaken. Deze technologieën zijn essentieel voor de productie van biobased monomeren uit non-food grondstoffen.

\subsection{Overheidsbeleid}

Alle grote economieën hebben een wetgeving om te kunnen omgaan met problemen die samenhangen met de productie en consumptie van plastics. De voornaamste doelstelling 
van deze voorschriften is het terugbrengen van de hoeveelheid afval door recycling en via het beperken van het gebruik van plastic tasjes en disposables.

In de EU bestaan momenteel nog geen specifieke richtlijnen ter bevordering van biobased plastics of biobased chemicaliën. In de Verenigde Staten van Amerika is dit anders, de federale overheid heeft hier de rol van launching customer. In het federale inkoopprogramma krijgen biobased plastics via het 'Bio-preferred' programma de voorkeur boven reguliere plastic producten. Het idee hierachter is dat, als overheidsinstellingen biobased producten

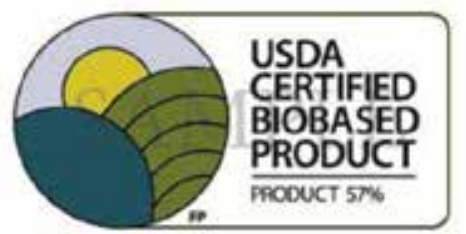
aanschaffen, dit de verkoop van een product op gang brengt. Hierdoor wordt de productie gestimuleerd en worden andere bedrijven ertoe aangezet deze producten aan te schaffen.

Alleen producten die op een officiële lijst van de federale overheid staan komen in aanmerking. Hiervoor worden de producten getest op het aandeel biobased en worden ze onderworpen aan een duurzaamheidscheck. Voor het aandeel biobased wordt een ASTM-standaard (American Society for Testing and Materials) gebruikt. Momenteel is deze gebaseerd op het percentage biobased koolstofatomen. Dit kan eenvoudig worden vastgesteld door toepassing van de koolstof-14 methode.

In de EU zijn richtlijnen voor verpakking, verpakkingsafval en storten van afval essentieel. Tot nu toe is de wetgeving gericht op het sluiten van de materialenkringloop. Minder nadruk wordt gelegd op de uitstoot van broeikasgassen en op het terugbrengen van de invloed van de levenscyclus (energieverbruik, andere emissies), al wordt hier bij de huidige verpakkingsbelasting in Nederland wel naar gekeken.

De meeste lidstaten belasten de producenten van afval. Veel landen belasten ook de producenten van elektrische en elektronische apparatuur. Composteerbare producten

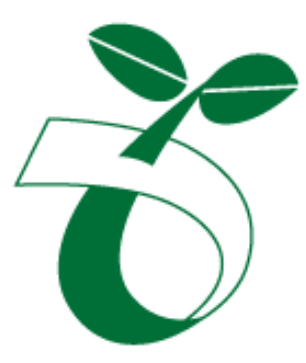

Composteerbaar worden vaak lager belast. Er bestaat ook wetgeving die vereist dat materialen in bepaalde producten biologisch afbreekbaar of composteerbaar zijn. Voor verpakkingsafval bestaat hiervoor een Europese CEN-norm (EN13432) voor composteerbaarheid. Azië (Japan) en Amerika (ASTM) hebben normen die vergelijkbaar zijn met deze standaard. Producten die voldoen aan deze norm komen in aanmerking voor het hier weergegeven kiemplantlogo. Het doel is dat producten die het kiemplantlogo mogen worden afgevoerd als organisch afval. Toch worden gecertificeerde composteerbare producten niet overal geaccepteerd. Omdat composteringsinstallaties de afgelopen 25 jaar sterk zijn veranderd en composteringscycli in deze installaties sterk 
zijn verkort zijn er vragen ontstaan of de EN13432 norm nog voldoen, én of producten die nu voldoen aan deze norm voldoende snel afbreken in de huidige composteringsinstallaties. Hiervoor is aanvullend onderzoek noodzakelijk onder praktijkomstandigheden. Daarnaast wordt gekeken waar composteerbare producten een voordeel bieden (zakjes voor inzameling van GFT, theezakjes en koffiepads, fruitstickers, .....). Met name deze producten zouden moeten worden toegelaten in GFT. Producten zoals composteerbare pennen, of zelfs schoenzolen moeten worden ontmoedigd.

\subsection{Toekomstperspectief}

Technisch gezien kunnen vrijwel alle huidige synthetische plastics en vezels worden vervangen door hun biobased tegenhangers ${ }^{7}$. Of dit zal gebeuren of niet hangt op de eerste plaats af van de vraag. Voor biobased plastics is het van belang dat de ingezette trend van een specifieke vraag naar biobased plastics doorzet. De vraag hangt vanzelfsprekend samen met het aanbod en de (productie) kosten welke weer direct gerelateerd zijn aan de reeds geïnstalleerde productiecapaciteit, de stand van de technologie en de mogelijkheden om te kunnen investeren. Het Ellen Mac Arthur model van "de nieuwe plastic economie" is daarbij een stimulans voor biobased plastics.

Gezien de beschikbare materialen binnen de markt voor biobased plastics (zie het schema op pagina 53) valt op dat deze producten zich hebben bewezen en klaar zijn om één ontwikkelingsfase verder te gaan zodra de vraag stijgt en investeringskapitaal beschikbaar is. Ook vanuit de R\&D-fase wordt de nodige nieuwe bedrijvigheid verwacht. Er zijn dan ook goede redenen om aan te nemen dat de ontwikkelingen elkaar snel zullen opvolgen de komende tijd.

Veel nieuwe fabrieken zijn de eerste in hun soort en veel toegepaste technologieën staan aan het begin van de leercurve. De lancering van nieuwe biobased plastics lijkt dan ook pas te zijn begonnen. De markt voor biobased plastics zelf verwacht een groei van meer dan $20 \%$ per jaar, en de wereldwijde productie zal daarmee in het jaar 2020 ongeveer 20 miljoen ton/jaar bedragen. Zelfs met deze verwachtingen zullen de nieuwe biobased plastics het komend decennium kwantitatief een bescheiden deel van de markt innemen. De verwachting is dat pas na 2020 de markt voor biobased materialen een grotere groei zal doormaken.

\footnotetext{
${ }^{7}$ Groene bouwstenen voor bio-based plastics. Paulien Harmsen en Martin Hackmann. Serie Groene grondstoffen.
} 


\section{Nabeschouwing}

Recente macro-economische ontwikkelingen laten zien dat de toekomst voorspellen zeer moeilijk is. Een crisis, maar ook een hoogconjunctuur, kunnen een verwoestend of juist stimulerend effect hebben op een groeimarkt. Zeker is dat bij de verdere ontwikkeling van de markt voor biobased plastics de volgende aspecten een belangrijke rol zullen gaan spelen:

Afhankelijkheid van grondstoffen

Agrogrondstoffen zoals zetmeel en suiker worden vrij verhandeld. Gezien het totale productievolume is het gedeelte dat wordt gebruikt voor biobased plastics in de meeste gevallen gering. Een (te grote) afhankelijkheid van één grondstof of productielocatie betekent een potentieel risico. Wanneer ook celluloserijke grondstoffen kunnen worden ingezet voor $2^{\mathrm{e}}$ generatie technologie zijn de mogelijkheden vrijwel onbegrensd.

Verlaging van de productiekosten

Bij bepaalde materialen zoals biobased PE, nylon 11 en cellulosefilms zit de ontwikkeling niet zozeer in het verbeteren van het eindproduct als wel op meer efficiënte, milieuvriendelijke en vooral goedkopere productiemethodes. Veel biobased polymeren zijn op dit moment duurder dan hun concurrenten. Dit probleem moet worden overwonnen door technische verbeteringen, het gebruik van goedkopere grondstof of het vergroten van de productieschaal. Inspiratie kan worden gehaald uit voorbeelden zoals biobased epoxyhars en biobased PUR. Kostenverlaging is bij deze materialen de belangrijkste drijfveer om over te stappen op biobased grondstoffen.

Verbreding van de toepasbaarheid

Plastics in vele varianten worden gebruikt voor specifieke markten. Wanneer een biobased plastic chemisch identiek is aan zijn synthetische tegenhanger (bijvoorbeeld biobased PE), zullen er geen problemen zijn voor gebruikers. In andere gevallen zullen de nieuwkomers hun toepasbaarheid moeten bewijzen (bijvoorbeeld PHA's voor verpakkingsdoeleinden). De verbetering van de materiaaleigenschappen van PLA in de afgelopen jaren laat zien dat er vaak nog veel mogelijk is.

Recycling en circulariteit

In toenemende mate zullen plastics recyclebaar moeten zijn en hergebruikt worden in zo hoogwaardig mogelijke toepassingen. Dit geldt zowel voor biobased als voor fossiele grondstoffen. Naast uitdagingen biedt dit ook kansen voor de ontwikkeling van nieuwe producten. Een belangrijk voorbeeld zijn laminaatverpakkingen, zoals barrière folies en veel PET-schalen, die geschikt zijn voor een topseal folie. Deze producten vormen een 
probleem in de (mechanische) recycling terwijl in organische recycling samengestelde producten goed verwerkt kunnen worden. 


\section{Referenties}

Dit boek is voornamelijk gebaseerd op de volgende publicaties:

Shen, L., Haufe, J., Patel, M., (2009) Product overview and market projection of emerging bio-based plastics, PRO-BIP 2009, Utrecht University.

Ravenstijn, J., (2010) The state-of-the-art on Bioplastics; products, markets, trends and technologies.

World Economic Forum and the Ellen MacArthur Foundation, The New Plastic Economy (2017)

Van den Oever, MJ H., Molenveld, K, Bos, HL, van der Zee, M. Bioplastics facts and figures (2017).

Bos, HL, Meesters, KPH, Conijn, SG, Corré, WJ, Patel, MK., Sustainability aspects of biobased applications (2010)

Bos, HL, Meesters, KPH, Conij, n SG, Corré, WJ, Patel, MK., Accounting for the contrained availability of land: a comparison of bio-based ethanol, polyethylene, and PLA with respect to non-renewable energy use and land use, Biofuels, Bioprod. Bioref. 6: 146-158 (2012)

European Bioplastics, Bioplastics Market Data (2017)

Molenveld, K, Van den Oever, MJ A. Biobased Packaging Catalogue (2015)

Bolck, C, Ravenstijn, J. Molenveld, K. Biobased Plastics 2012 (2011) 


\section{Verklarende woordenlijst}

\section{Amorf}

Een amorf polymeer (of een amorfe fractie van een polymeer) kent geen geordende (kristallijne) structuur. Bij een temperatuur onder de stollingstemperatuur (of $\mathrm{Tg}$ ) bevindt het polymeer zich in een ingevroren glasachtige toestand en boven de stollingstemperatuur veranderd het polymeer van rubberachtig naar stroopachtig tot vloeibaar als functie van de temperatuur. Amorfe polymeren/kunststoffen zijn meestal transparant, een voorbeeld is PMMA (plexiglas).

\section{Blaasmiddel}

Een blaasmiddel is een chemische stof of stuwgas die gebruikt wordt om een polymeer te schuimen.

\section{Blenden}

Een polymere blend is een mengsel van minimaal twee polymeren die in dit mengsel een nieuw materiaal met andere eigenschappen vormen.

\section{Branching agents}

Branching agents zijn additieven die gebruikt worden om vertakkingen aan te brengen aan (lineaire) polymeerketens.

\section{Bulk polycondensatieproces}

Een polycondensatie proces is de chemische reactie van monomeren tot een polymeer onder afsplitsing van een klein molecuul zoals water of methanol. Polymeren zoals polyesters, polyamiden of polyethers worden vaak via polycondensatie reacties geproduceerd. Wanneer het proces wordt uitgevoerd zonder toevoeging van een medium op de monomeren op te lossen maar uitgaande van zuivere (gesmolten) monomeren wordt gesproken van een bulk polycondensatieproces.

\section{Cellofaan}

Cellofaan is een transparante folie op basis van geregenereerde cellulose. Cellofaan is biobased omdat het wordt geproduceerd uit hernieuwbare grondstoffen.

\section{Chain-extenders}

Chain-extenders of ketenverlengers zijn additieven die 2 of meer reactieve groepen bezitten en via deze reactieve groepen 2 of meer polymeerketens aan elkaar kunnen knopen. 


\section{Composiet}

Een composiet is een materiaal dat is opgebouwd uit verschillende componenten. Vaak wordt de term gebruikt voor vezelversterkte kunststoffen.

\section{Compounderen}

Compounderen of extrusie compounderen is het proces dat wordt gebruikt om één of meer polymeren te mengen met additieven, resulterend in een plastic compound.

\section{Copolyesters}

Polyesters zijn polymeren waarbij de monomeren via een esterbinding zijn verbonden, bijvoorbeeld door combinatie van dizuren en diolen. Wanneer aan het mengsel van dizuur en diol een additioneel dizuur en/of diol wordt toegevoegd wordt gesproken van copolyesters. Een voorbeeld van een copolyester is PEIT dat bestaat uit PET met isosorbide als additioneel diol.

\section{Copolymerisatie}

Copolymerisatie is het opbouwen van polymeren uit 2 of meer monomeertypen

\section{Dissolving pulp}

Een dissolving pulp (of dissolving cellulose) is een cellulose pulp met een zeer hoog cellulose gehalte $(>90 \%)$. Dissolving pulp heeft speciale eigenschappen zoals een hoge witheid en een uniforme molecuulgewichtsverdeling. Het wordt gebruikt voor de productie van cellulose derivaten zoals cellulose acetaat en geregenereerde celluloses (cellofaan, rayon).

\section{Dubbele binding}

Een dubbele binding is een chemische binding tussen twee atomen waarbij twee gemeenschappelijke elektronenparen betrokken zijn. Een chemische verbinding die een dubbele binding bevat wordt een onverzadigde verbinding genoemd. Onverzadigde vetzuren zijn een voorbeeld van onverzadigde verbindingen.

\section{Elastomeren}

Elastomeren zijn elastische stoffen met als belangrijkste kenmerk dat zij na een opgelegde vervorming weer terugkeren naar de oorspronkelijke vorm. 


\section{E-modulus}

Elasticiteitsmodulus E (ook wel Young's modulus genoemd), is een materiaalkundige eigenschap van een materiaal die een maat is voor de stijfheid of starheid van een materiaal.

\section{Epoxyharsen}

Epoxy is een thermohardende kunststof, die kan worden gebruikt om composieten mee te vervaardigen Het is een tweecomponenten hars (lijm) en wordt voor vele toepassingen gebruikt, zowel industrieel als huishoudelijk. Epoxy kan aangebracht worden als afdeklaag (coating), maar ook in combinatie met (glas) vezels.

\section{Extrusie}

Extruderen is een vormgevingstechniek waarbij een vervormbaar materiaal (gesmolten polymeer) door een matrijs geperst wordt. In de matrijs zitten één of meerdere min of meer complex gevormde gaten die het uiteindelijk gevormde staafmateriaal, het extrusieprofiel, zijn vorm geeft. Dit kan een massief of hol profiel zijn.

\section{Extrusieschuimen}

Het maken van een geschuimd product via extrusie door toevoeging van een blaasmiddel aan het gesmolten polymeer. Wanneer het polymeer de extruder verlaat schuimt het op omdat de druk buiten de extruder lager is dan in de extruder.

\section{Fermentatie}

Fermentatie is in de biochemie het omzetten van biologische materialen met behulp van bacteriën, celculturen of schimmels in afwezigheid van zuurstof (anaeroob)). Ook het toevoegen van enzymen kan leiden tot fermentatie. Het wordt tegenwoordig gebruikt voor alle processen in de biochemie waarbij biologische producten worden geproduceerd.

\section{Folieblazen}

Folieblazen - ook wel extrusierekblazen genoemd - is een zeer specifieke techniek voor de fabricage van folies. Uit de spuitkop van de extruder komt een buis met een heel dunne wand. Deze wordt met lucht opgeblazen, waardoor in een continu proces een enorme plastic ballon ontstaat. Als die afgekoeld is, wordt de folie opgerold en eventueel opengesneden tot bijvoorbeeld zakken. Producten die door middel van folieblazen worden gemaakt zijn plastic tassen, zakken en folies. 


\section{Geacryleerde}

Acryleren is het voorzien van een verbinding van een acrylaat groepen $(\mathrm{CH} 2=\mathrm{CHOO}-$ ).

\section{Geëpoxideerde}

Epoxideren is het voorzien van een verbinding van een epoxide groep. Een epoxide is een cyclische ether met slechts drie ringatomen. Epoxides reactiever zijn dan andere ethers.

\section{Geregenereerde celluloses}

Geregenereerde cellulose zoals cellofaan en rayon zijn chemisch identiek aan cellulose en worden gemaakt uit dissolving pulp via een chemisch proces (het viscose proces of het nieuwe lyocell proces).

\section{Glasovergangstemperatuur}

De glastemperatuur $(\mathrm{Tg})$ is de temperatuur waarbij een amorfe vaste stof zoals een glas of polymeer, bros wordt bij koeling, of zacht bij verwarming. Glasovergangstemperaturen zijn vooral bij polymeren van groot belang. Hoewel sommige polymeren (zoals polyethyleen) ook (semi-) kristallijne vaste stoffen kunnen vormen, zijn de meesten niet (of niet goed) in staat een regelmatige stapeling van hun moleculen in een kristalrooster te ondergaan. Zij blijven daarom gemakkelijk tot onder hun eigenlijke smeltpunt vloeibaar. Bij een lagere temperatuur ( $\mathrm{Tg}$ ) ondergaan zij echter toch een stollingsproces, waarbij veel van de bewegingsvrijheid van de polymeerketens verdwijnt.

\section{Heat deflection temperature (HDT)}

De HDT is de temperatuur waarbij een polymeer of plastic vervormd onder een opgelegde kracht. De HDT is een belangrijke eigenschap binnen productontwerp van plastic producten. De HDT wordt ook wel de maximale gebruikstemperatuur genoemd. De HDT wordt bepaald via een vastgestelde testprocedure die beschreven staat in de ASTM D648 norm.

\section{Hydrogeneren}

Hydrogeneren is waterstof toevoegen aan de moleculen van een stof zonder dat daarbij een andere stof afsplitst. Onverzadigde verbindingen worden door hydrogeneren "verzadigd". 


\section{Hydrolyse}

Hydrolyse is de splitsing van een chemische verbinding onder opname van water. Bijvoorbeeld: de esterverbinding ethylacetaat valt samen met water weer uiteen in de stoffen waaruit het is gevormd namelijk azijnzuur en ethanol. Hydrolyse kan worden gezien als het omgekeerde van een condensatiereactie met afsplitsing van water.

\section{Hydroxylgroep}

Een hydroxylgroep is in de chemie een functionele groep bestaande uit een zuurstof- en een waterstofatoom, die via het zuurstofatoom aan de rest van een molecuul vast zit. Soms wordt er ook wel naar verwezen als een - $\mathrm{OH}$ groep of een alcoholgroep.

\section{I mpact modifier}

Een impact modifier is een rubber of elastomeer materiaal dat als additief wordt toegevoegd aan een kunststof om de impact eigenschappen de verbeteren. De impact eigenschappen is de weerstand tegen breuk bij een plotselinge opgelegde kracht (botsing).

\section{Kristalliniteit}

De kristalliniteit van een polymeer is de mate waarin het polymeer kristallijne (geordende) fasen bevat. Polymeren zijn nooit 100\% kristallijn, maar semikristallijn. Semi-kristallijne materialen hebben naast een glasovergangstemperatuur ( $\mathrm{Tg}$ ) tevens een smeltpunt $(\mathrm{Tm})$ en hebben in tegenstelling tot amorfe polymeren goede mechanische eigenschappen boven de glasovergangstemperatuur.

\section{Loose fill schuimen}

Loose fill schuimen is de losse vulling die wordt gebruikt voor het opvullen van lege ruimten in verpakkingen. Traditioneel worden loose fill schuimen gemaakt van polystyreen. Losse vulling gemaakt van (maïs)zetmeel is honderd procent biologisch afbreekbaar en derhalve geschikt voor composteren. Het productieproces voor losse vulling van (maïs) zetmeel is laag in energieverbruik en vereist geen chemicaliën, alleen water.

\section{Nucleating agents (kiemvormers)}

Een nucleating agent of kiemvormer is een additief dat startpunten geeft voor het vormen van kristallieten in een gesmolten polymeer. 


\section{Rayon}

Rayon is een "door de mens gemaakte" geregenereerde cellulose vezel. Rayon is biobased omdat het wordt geproduceerd uit hernieuwbare grondstoffen en is een semisynthethische of kunstmatige vezel. Rayon is in de textielindustrie ook bekend onder de namen viscose en kunstzijde.

\section{Ring-opening polymerisatie}

Een ring-opening polymerisatie is het vormen van een polymeer uit cyclische verbindingen. Met behulp van een katalysator breekt een cyclische verbinding open en deze zorgt voor ringopening van een volgend monomeer. Op deze manier ontstaan een ketenreactie en een polymeer. Voorbeelden van een polymeer dat via ring-opening polymerisatie wordt gemaakt is PLA (polymelkzuur) uit lactide.

\section{Smeltsterkte}

Smeltsterkte is in de polymeer technologie een maat voor de rekviscositeit, en is gedefinieerd als de maximale spanning die kan worden opgelegd aan een smelt zonder dat deze breekt. De smeltsterkte van polymeren is bijvoorbeeld belangrijk bij folieblazen, en het spinnen van vezels uit een polymeer smelt. De smeltsterkte van een polymeer kan verbeterd worden door vertakkingen aan te brengen aan een polymeer.

\section{Spinnen van vezels}

Vezels worden gesponnen vanuit een vloeibare toestand. Voor thermoplastische polymeren is dit een smelt en voor niet smeltbare polymeren (zoals cellulose) een oplossing. De vloeistof wordt door een spinneret (plaat met hele fijne gaatjes) geperst en door afkoeling van de smelt of door het verdampen van het oplosmiddel wordt het polymeer vast en ontstaat een dunne vezel.

\section{Spuitgieten}

Spuitgieten is een vormgeeftechniek die meestal wordt toegepast voor thermoplastische (smeltbare) polymeren. Tijdens het spuitgietproces wordt een polymeer gesmolten en onder hoge druk ingespoten in een matrijs (of mal) waarvan de holte de vorm is van het gewenste ( 3 dimensionale) product. Door afkoeling stolt het polymeer tot een product. Spuitgieten is een van de meest gebruikte vormgevingstechnieken voor kunststof onderdelen. 


\section{Stabilisatoren}

Polymeer stabilisatoren worden toegevoegd aan polymeren om ongewenste reacties zoals oxidatie en ketenbreuk tegen te gaan die worden veroorzaakt door bijvoorbeeld UV licht of hoge temperaturen.

\section{Stereo complexes PLA (sc-PLA)}

Sc-PLA wordt gevormd uit een mengsel van PLLA en PDLA. Het smeltpunt van sc-PLA is ca. $230^{\circ} \mathrm{C}$, in is veel hoger dan het smeltpunt van PLLA of PDLA $\left(170^{\circ} \mathrm{C}\right)$.

\section{Thermovormen}

Thermovormen of vacuümvormen is een techniek waarbij uit dikke plastic folies (0.2-2 $\mathrm{mm}$ ) gevormde producten worden gemaakt. Hiervoor wordt het materiaal eerst verwarmd. Voorbeelden van typische thermovorm producten zijn plastic bekertjes, plantenpotjes en dunne plastic schaaltjes.

\section{Vetzuren}

Vetzuren zijn organische zuren met een keten van ten minste 2 koolstofatomen en een carboxylgroep ( $\mathrm{COOH})$. Vetzuren zitten in vetten. Vet is een verbinding van glycerol en 3 vetzuren. Bekende vetzuren zijn oliezuur, stearinezuur, linolzuur en palmitinezuur.

\section{Viscose}

Viscose is een stroperige organische vloeistof die wordt gebruikt bij de productie van rayongarens en cellofaan. Ook wordt de naam viscose als synoniem gebruikt voor rayon.

\section{Weekmakers}

Weekmakers zijn verbindingen die kunststoffen flexibel maken. Wanneer aan een plastic (zoals PVC, harde PVC buizen) een weekmaker wordt toegevoegd wordt de Tg verlaagd zodat het plastic rubberachtig wordt (PVC slangen, vinylvloerbedekking).

Weekmakers zijn vaak esters en bekende weekmakers zijn ftalaatesters zoals dioctylftalaat (DOP) en di-butylftalaat (DBT). Weekmakers zitten fysische niet vast aan het polymeer en kunnen migreren uit een kunststof en in het milieu terecht komen. 


\section{Colofon}

\section{Biobased Plastics 2019}

Karin Molenveld en Harriëtte Bos (Wageningen Food \& Biobased Research)

2019, derde herziene druk

(c) Wageningen Food \& Biobased Research

ISBN: 978-94-6343-541-3

DOI: https://doi.org/10.18174/464407

Druk: Propress, Wageningen

Wageningen Food \& Biobased Research

Bornse Weilanden 9

Postbus 17

6700 AA Wageningen

https://www.wur.nl/wfbr

Zijn er relaties die u met dit boek een plezier kunt doen dan zouden we dat graag van u vernemen.

Deze publicatie is mede mogelijk gemaakt door de TKI-BBE en door het beleidsondersteunend onderzoeksthema Biobased Economy (BO-20.12), gefinancierd door het Ministerie van Economische Zaken en Klimaat. Het is de eenentwintigste in een reeks publicaties over het gebruik van agrogrondstoffen en nevenstromen in veilige en gezonde producten voor consumenten- en industriële markten (zie ook www.groenegrondstoffen.nl en www.biobasedeconomy.nl). 



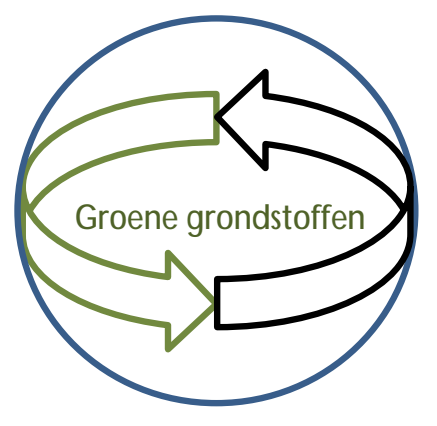

